\title{
Giden Arama Yapan Müşteri Temsilcilerinin Sorunlarının Belirlenmesine Yönelik Nitel Bir Araştırma
}

\section{A Qualitative Research Towards Identifying Problems of Customer Representatives Responsible for Outbound Calls}

\section{Ebru Kanyılmaz Polat ${ }^{1}$ (i)}

Öz

Bilişim teknolojisinde yaşanan gelişmeler sonucunda işletme- müşteri iletişiminde geleneksel iletişim yerini "çağrı merkezleri" almıştır. Günümüzde çağrı merkezleri uluslararası bir sektör haline gelmiştir. Türkiye'de 2019 yılında bu sektörde çalışanların sayısı 117 bine yükselmiştir. Müşteri temsilcisi olarak anılan bu çalışanların sayışandaki artışa rağmen sektördeki çalışma koşullarının olumsuzluğu dikkat çekmektedir. $\mathrm{Bu}$ araştırmada dış hizmet sağlayıcı olarak giden arama yapan bir banka çağrı merkezi ekibinin çalışma koşulları nitel bir araştrrma ile incelenmiştir. 10 müşteri temsilcisi ile görüşme gerçekleştirilmiş, sonuçlar MAXQDA Analytics Pro 2020 nitel analiz programı ile analiz edilmiştir. Araştırma sonunda çalışanların uzun çalışma saati, kısa mola süreleri olduğu, yüksek hedef ve satış baskısı altında oldukları, sıkı denetim ve kat performans değerleme sistemlerine tabi tutuldukları tespit edilmiştir. Ek olarak çalışanların uzun saatler boyunca telefonla konuşmaktan dolayı çeşitli sağlık sorunları yaşadıkları, kaba müşteri ve yönetici tutumundan dolayı stres altında oldukları belirlenmiştir. Çalışanların sendikalı olmadıkları ve sendikalar hakkında yeterli bilgiye sahip olmadıkları görülmüştür. Diğer yandan çoğunluğu genç olan çalışanların bu sektörü geçici bir iş olarak gördükleri, işlerinde bir gelecek düşünmedikleri belirlenmiştir.

Anahtar Kelimeler

Çağrı Merkezi, Müşteri Temsilcisi, Çalışma Koşulları, Giden Çağrı, Denetim

\begin{abstract}
As a result of developments in information and communication technology, "call centers" have replaced instead of traditional communication in business-customer communication. Today, call centers have become an international industry. The number of employees in this sector in Turkey increased to 117 thousand in 2019. Despite this increase in the number of these employees, referred to as customer representatives, the unfavorable working conditions in the sector draw attention. In this study, the working conditions of a
\end{abstract}

1 Sorumlu Yazar: Ebru Kanyılmaz Polat (Dr. Öğr. Üyesi), Çanakkale Onsekiz Mart Üniversitesi, Biga Uygulamalı Bilimler Fakültesi, Uluslararası Ticaret, Lojistik ve İşletmecilik Anabilim Dalı, Çanakkale, Türkiye. E-posta: ekanyilmaz@comu.edu. tr ORCID: 0000-0002-3396-0791

Atıf: Kanyilmaz Polat, E. (2020). Giden Arama Yapan Müşteri Temsilcilerinin Sorunlarının Belirlenmesine Yönelik Nitel Bir Araşttrma. Sosyal Siyaset Konferansları Dergisi, 79, 399-439. https://doi.org/10.26650/jspc.2020.79.0005 
bank call center team performing outbound calls as an external service provider were examined by qualitative research. Interviews were conducted with 10 customer representatives, the results were analyzed by MAXQDA 2020 PRO qualitative analysis program. At the end of the research, it was determined that employees have very long working hours, short break times, they are under high target and sales pressure, they are under constant control, they are subjected to strict performance evaluation systems. Also, employees have various health problems due to talking on the phone for long hours, and they were found to be under stress due to rude customer and manager attitudes. It was observed that the employees were not unionized and did not have sufficient information about the unions. On the other hand, it has been determined that the majority of young employees see this sector as a temporary job and do not think about a future in their work.

\section{Keywords}

Call Center, Customer Representative, Working Conditions, Outbound Call, Audit 


\section{Extended Summary}

With the rise of information and communication technologies, call centers have emerged as a new sector instead of face-to-face communication in companies' relations with customers. Call centers are increasing their number as a new business area that begins to grow rapidly after information society. Although call center employees are white-collar employees of the information society, they look similar to the Fordist production system in terms of working conditions and are exposed to Taylorist principles. These young people mostly graduated from higher education, well-dressed and beautifully speaking Turkish, look like a young plaza employee, are employed like industrial revolution workers in exchange for a full-time and insured job, have taken a current form. Call centers are working areas with unfavorable working conditions where routine and standard jobs are done, workloads, control, and labor turnover rates are very high. The advantages experienced by the information worker are not out of the question for call center employees, and these employees are unable to avoid exposure to bad conditions similar to the industrial revolution. As of these characteristics, some authors (Taylor and Bain, 1999; Başbug et al. 2010: 260; Özkan, 2013: 65; Doğanay, 2016: 53; Bulut ve Ataay, 2017: 4-5; YücesanÖzdemir, 2019: 199) call centers are depicted as the factories of the modern world "an assembly line in the head".

In this research, it was tried to determine the problems of customer representatives working in call centers in their working life. There is some research on the problems of customer representatives receiving incoming searches in the literature. However, there is no research on the problems of customer representatives who makes an outbound calls. Therefore, outbound call customer representatives were selected as a working group. Phenomenology design was preferred because it was aimed to reveal the problems faced by the participants with their own experiences. In this context, answers for the following questions were sought in the research;

Research Question 1) What are the problems faced by customer relations representatives?

Research Question 2) Do the problems faced by responsible representatives for incoming calls differ from the problems of the responsible persons for outbound calls? 
The bank (outbound call) team of a company providing call center services in the finance, public, energy, telecommunications, local government, and e-commerce sectors with 14 branches, more than 12,000 employees in Turkey, Bursa office was selected as a sample. "Convenience Sampling" is used in sample selection. To identify employee problems, customer representatives were included in the research, team leaders and chefs in the managing group were excluded.

Data in the research were obtained by interviewing qualitative research methods. The semi-structured interview form was used in the interview. In total, the meeting with 12 customer representatives was targeted, and the interviews were terminated at 10 upon seeing that the responses were dropped again. Data obtained from the interviews were analyzed through the MAXQDA 2020 PRO qualitative analysis program.

According to the findings, all participants began to experience complaints such as hearing loss, chronic pharyngitis, and vocal cords, headaches after starting to work in the call center.. Working hours are 45 hours a week, but "if necessary" employees are also employed at the weekend, and this work is not considered as overtime work. Employees work with minimum wage plus premium, but the conditions for receiving premium are difficult due to high goals, completing calls in a very short time, and making no mistakes. Participants stated that the fee and premium were too insufficient for their work. Along with prolonged phone calls, the unsympathetic, rude, or even abusive conversations of customers cause great stress on the employees.

Another important point that makes working conditions challenging is the daily call times received and the break times used in return. As a result of the automatic computer distributor of calls, a new call is connected to the customer representative whose phone is turned off at an interval of almost 10 seconds. This suggests that participants spend a significant time in the call, outside their break time. On the other hand, the calls made are recorded and the employees are under strict and constant supervision. Team leaders are also constantly circling and overseeing among employees. Customer representatives who do not receive calls for a few minutes are checked, ensuring that the new call is connected immediately.

Another factor that distracts call centers from being workable places is the 
limitation of career opportunities. Within call centers, career opportunities are limited to team leader and chief. Participants talk about merit issues in promotions and express that elevation are often provided from outside the institution. The workloads, lack of high qualifications, standardization, and the limitation of elevation opportunities lead employees to see call centers as a "temporary job".

In addition to all these problems, the outbound customer representatives are also under sales pressure. The high goals also pose compelling pressure on employees. High targets are set to create sales pressure, and higher targets are given to those who achieve these goals by performing superior performance on the same day.

Although many problems in the sector were revealed in 2013 by a report prepared by the Ministry of Labor and Social Security, no problem could be corrected till this research was conducted in 2020. It is known that the unionization rates of call center employees are very low. In this study, it was found that the participants had incomplete knowledge of trade union rights. Participants, on the other hand, have a positive attitude that their problems can be reduced by trade unions. Improving awareness of the employees' union rights will increase unionization rates. Among the important steps to improve working conditions in this sector are trade union struggling, putting legal lower limits on break times used in exchange for talk times, health problems correspondingly include the addition of wear share to employee pension calculations. 


\section{Giden Arama Yapan Müşteri Temsilcilerinin Sorunlarının Belirlenmesine Yönelik Nitel Bir Araştırma}

Yirminci yüzyıl, üretim süreçleri açısından bilginin egemenliğinin başladığı yıllar olarak kabul edilebilir. Amerika, Japonya, Batı Avrupa gibi ülkelerde 1960'lardan sonra her sektörün içinde yoğun olarak bilgi teknolojilerinin kullanımı ile gelinen aşama bilgi toplumu olarak adlandırılmaktadır. Bilgi toplumu, yeni teknolojilerin üretim sürecine girmesi ile bilgi üretimi ve sermayesinin, nitelikli insan gücünün önem kazandığ 1 ve bilginin bir sektör olarak ortaya çıktığı gelişmeler olarak tanımlanabilir (Selvi, 2012: 196). Bilgi ve teknolojinin üretime katılmasıly mal üreten ekonomilerden bilgi üreten ekonomilere geçiş yaşanmıştır. Bilgi toplumunda ekonomik büyümenin kaynağı bilginin üretilmesi ve işlenmesi haline gelmiştir. Sanayi toplumundaki maddi sermayenin yerini bilgi toplumunda "insan ve bilgi”" sermayesi almıştır. Bilgi toplumunda fabrikalarda gerçekleşen sanayi üretimi yerini bilgisayarlar aracılı̆̆ıyla yapılan üretime, kol gücü ise yerini beyin gücüne bırakmıştır. Sanayi toplumunda üretimin temel ögesi olan sanayi malları yerine bilgi toplumunda bilgi ve teknoloji üretimi söz konusudur. Bu üretim sürecinin başlıca aktörleri bilgisayarlar, iletişim ve elektronik araçlar, robotlar, elektronik haberleşme ve yeni teknolojilerdir (Aktan ve Tunç, 1998: 125-127).

Yaşanan değişim yirminci yüzyılın ikinci yarısından itibaren işgücünün sektörel dağılımını hızla hizmetler sektörüne kaydırmıştır. Diğer yandan bilgisayar, iletişim gibi teknolojisi yüksek yeni bir sektör de aynı hızla yükselmiştir. Bu toplumda talep edilen işgücünün nitelikleri araştıran, problem çözen, karar verme ve sorumluluk alma yetisine sahip, etkili konuşma, sunma ve raporlama tekniklerine hakim eğitimli işgücü olarak kabul edilmektedir (Erdem, 2005: 552- 553). Bilgi üreten çalışanlar bilgi toplumunda önemli kazanımlar elde ederken, bilgiyi kullanan işgücü için süreç aynı avantajları getirememiştir. Bilgi toplumunun rutin ve daha niteliksiz işlerini yapmak durumunda kalan beyaz yakalılar için bu süreç iş güvencesinden yoksun, belirsiz ve esnek bir görünümdedir (Zaim, 2005: 599- 600).

Bilgi çağının ortaya çıkardığ 1 yeni mesleklerden biri de "çağrı merkezi çalışanlarıdır”. Çağrı merkezleri bilişim teknolojilerin getirdiği olanaklarla işletmelerin çeşitli yerlere şube açmak yerine müşterilerin 7/ 24 işletmeye ulaşmasına olanak tanıyan yeni bir çalışma organı olarak hızla yayınlık kazanmıştır. Bütün sektörlerde yaygın olarak kullanılan bu merkezler müşteri 
sorunlarını çözmek ve kusursuz hizmet vermek odaklı çalışmaktadırlar. Bilgi çağının olanak ve nitelikleri ile çalışan bu işçiler beyaz yakalı nitelikleri taşımakla birlikte, beyaz yakalıların işgücü piyasalarında sahip oldukları avantajlara ulaşamamaktadırlar. Yapılan işin çok fazla nitelik gerektirmemesi, müşteriler ile yapılan rutine binmiş görüşmeler, otomatik olarak yönlendirilen çağrılar ve görüşmelerin kayıt altına alınarak kontrol edilmesi ve saniyelerle ifade edilen aralıklarla görüşmeleri bitirme baskısı bu durumun başlıca nedenleridir. Çalışma şartları ve çalışanlardan beklentileri değerlendirildiğinde çağrı merkezleri bazı yazarlarca Taylorizmin yeni biçimi, Fordist üretim bandının şekil değiştirmiş hali olarak ele alınmaktadır (Taylor ve Bain, 1999; Keser, 2002: 102; Man ve Selek Öz, 2009: 81-82). Bu çalışma şartları çalışanlar üzerinde yoğun baskı ve stres oluşturmaktadır. Bilgi toplumundaki bilgiyi üreten kesim dışında kalan ve nispeten esnek ve belirsiz çalışma şartlarına maruz kalan bu işgücünün çalışma koşulları incelenmesi gereken önemli bir konular arasındadır.

\section{Çağrı Merkezi Sektöründe İstihdam}

Teknoloji ve bilişim sektöründe yaşanan gelişmeler müşterilerle hem daha hızlı hem de karlı şekilde iletişime geçmenin önünü açmıştır. İletişim teknolojilerinin geldiği nokta her yere şube açmadan müşterilerin her istediklerinde işletmelere ulaşmasını mümkün kılmıştır. Güncel telekomünikasyon araçları ile sağlanan bu olanaklar yeni bir çalışma formu olarak "çağrı merkezi” kavramını doğurmuştur. Çağrı merkezleri hızla tüm dünyada bir sektör olarak oluşmaya başlamıştır.

Çağrı merkezleri şirketlerin telekomünikasyon aracılığı ile müşterileri ile iletişim kurması mantığına dayanmaktadır (Keser, 2006: 102). En genel tanımla çağrı merkezi işletme ile iletişime geçmek isteyen müşteri ya da diğer kişilerin telefon, interneti faks ya da posta ile iletişimine olanak sağlayan, bu iş için profesyonel bir ekibin istihdam edildiği sektörlerdir (Menteşe ve Es, 2017: 25). Diğer bir tanımla çağrı merkezi, işletmelerin temas içinde oldukları kişilerle iletişimlerini yürütmek için kullandıkları yazılım, donanım ve personelden oluşan merkezlerdir (Çelik, 2016: 1446).

Telefon ve bilgisayar teknolojilerinin bir arada kullanıldığı bu yerlerde çalışanlar giden ya da gelen telefonlarla müşterilerle iletişim kurmakta, yapılan görüşmeler otomatik dağıtım sistemi ile işlenip kontrol edilmektedir (Doğanay, 
2016: 38). Günümüzde bilgi ve teknolojik gelişmelerin geldiği nokta, ticaretin ulusal sınırları aşması, online alışveriş oranlarının artması ile çağrı merkezleri profesyonel olarak ele alınan bir sektör haline gelmiştir. Çağrı merkezleri aracılığıyla hem müşteri hizmetleri telefon aracılığı ile verilerek maliyetler azalmakta hem de müş̧eri her istediğinde şirkete ulaşabilmektedir. İnternet üzerinden yapılan işlemler yaygınlaştıkça çağrı merkezlerinin önemi ve çalışan sayısı da aynı oranda artmaktadır.

Çağrı merkezlerinin kuruluş yılları 1960'lara kadar uzanmaktadır. Ford marka otomobiller ile ilgili müşteri şikayetlerinin iletilmesi için devreye sokulan 800 ile başlayan telefon hattı çağrı merkezinin ilk örneği olarak ele alınabilir. Başka markaların da hızla kullanmaya başladığı bu hizmet şirketler açısından bir rekabet unsuru olarak görülmeye başlanmıştır (Keser, 2006: 101). Amerika Birleşik Devletleri'nin ardından diğer ülkelerde de yaygınlaşmaya başlayan bu hizmetlerin ilk örneği 1988 yılında bir bankanın çağrı merkezi kurması ile Türkiye'de de görülmüştür (Menteşe ve Es, 2017: 27). Bankalar ve cep telefonu şirketlerinin ardından diğer sektörlere de yaygınlaşan çağrı merkezleri 1996 yılı sonrası tüm Türkiye'de yaygınlaşmaya başlamıştır (Çelik, 2016: 1446).

Türkiye'de çağrı merkezlerinin hızlı yayılımı 2011 yılından sonra yaşanmıştır. Çağrı Merkezleri Derneği'nin (ÇMD) raporlarına göre 2011 yılında Türkiye'de 1057 çağrı merkezi bulunmaktayken bu sayı 2015 yılında bu sayı 1214'e ulaşmıştır. O tarihte sektörün pazar büyüklügü 3.6 milyar TL iken 2019 yılında sektörün pazar payı 2018 yılına göre \% 21 oranında büyüme ile 7.5 milyar TL'ye ulaşmıştır (ÇMD, 2019).

Pazar payının büyümesi ile paralel olarak sektörün yarattığı istihdam hacmi de hızla artmaktadır. Türkiye'de çağrı merkezinde istihdam edilenlerin Türkiye'de bu sektörün sağladığ istihdam 2018 y1lında \% 5,5 artarak 96 bin kişiye, 2019 yılında ise 107 bini müşteri temsilcisi olmak üzere 117 bin kişiye ulaşmıştır. 2020 yılı beklentileri ise çağrı merkezi çalışanlarının sayısının 107 bine, toplam istihdamın 117 bine yükselmesi yönündedir. 2017 yılında 2.5 milyar olan gelen giden arama sayısı 2018 yılında 3.2 milyara yükselmiştir (ÇMD, 2019). Bu rakamlar çağrı merkezi sektöründe yaşanan istihdam artışını gözler önüne sermektedir. Sektör her sene giderek büyümektedir. Böylece hem pazar hem de istihdam payı açısından çağrı merkezlerinin Türkiye ekonomisinde önemli bir yer edindiği söylenebilir. 
Çağrı merkezi sektöründe yaşanan istihdam artışı yanında istihdamın genel profili de dikkat çekmektedir. Çağrı merkezi çalışanlarının genel profili incelendiğinde 2018 yıl için çalışanların \% 64'ü kadınlardan oluşmaktadır. Çalışanların \% 66'sı üniversite mezunu iken yaş ortalaması 26'dır (ÇMD, 2019). Türkiye Bankalar Birliği (TBB) tarafından 25 bankanın çağrı merkezi çalışanlarının ele alındığı çalışmada müşteri temsilcilerinin yaş ortalaması 27 , destek hizmetlerinde çalışanlarda 32, yöneticilerde 34 olarak tespit edilmiştir. Raporda çalışanların eğitim düzeyi ise \% 12 lise, \% 32 ön lisans, \% 56'sı lisans mezunu olarak sunulmuştur (TBB, 2019). Bu oranlar günümüz üniversite mezunu gençlerin bu sektörde yoğunlukla istihdam edildiğini göstermektedir. Yükseköğrenim mezunu genç işsizlik oranlarının yüksek olduğu Türkiye'de iş bulamayan mezun gençlerin çağrı merkezlerini eğitimlerinin karşıllğ̆ olmasa da bir istihdam kapısı olarak gördüğü düşünülebilir.

Çalışma süreleri açısından incelendiğinde 2019 yılında çağrı merkezlerinde istihdam edilenlerin \% 46'sının çalışma süresi 1-2 yıl aralığında yer almıştır. Diğer bir ifade ile sektörde çalışanların yarısına yakını 2 yıl dolmadan bu işten ayrılmışlardır. Üç ve daha fazla yıldır sektörde çalışanların oranları \% 32'dir. Çağrı merkezi istihdamının \% 65'i telekomünikasyon, finans ve kamu sektöründe istihdam edilmektedir. ÇMD tarafından sunulan araştırmada sektörde genç işgücü, esnek yapılanma, yüksek teknoloji kullanımı ve müşteri deneyimlerinin sektörün gelişmeye açık tarafları olarak ele alınırken, nitelikli işgücü ihtiyacı, markalar ve kamuoyu açısından algı ve konumlandırma, teşvik ihtiyaçları gelişime açık alanlar olarak belirtilmiştir (ÇMD, 2019).

Çağrı merkezi sektörünün tüm dünya gibi Türkiye'de de hızlı gelişen sektörlerden biri olduğu görülmektedir. Sektörün istihdam yaratma kapasitesi ve gelişmeye açık yönleri yanında esnek iş yapılanması, yüksek işgücü devir hızı, kariyer olanaklarının sınırlı olması ve yıpratıcı çalışma koşulları çalışanlar açısından pek çok dezavantajlı durumu da beraberinde getirmektedir. Özellikle eğitim düzeyi yüksek, genç istihdamı yaratması bakımından güçlü bir sektör olarak görünmesi bu sektördeki çalışma koşullarının iyileştirilmesini gerekli kılmaktadır. Aksi halde sektördeki istihdam hacmi yeni mezun gençlerin işsiz kalma alternatifi bir iş olanağı olarak gördüğü, kalıcı olarak çalışmayı düşünmedikleri, mutsuz ve isteksiz çalıştıkları iş alanları olmaktan öteye gidemeyecektir. 


\section{Çalışma Merkezlerinde Çalışma Koşulları}

Çağrı merkezleri sayısı ve çalışanlarının sayısındaki hızlı yükselişin başlıca üç nedeninden bahsedilebilir. Birincisi; işletmenin satış yaptıktan sonra ürün ile ilişkisinin kesildiği anlayış günümüz ekonomik dünyasında geçerli değildir. Pek çok işletme müşteri odaklı olarak hedef, değer ve misyonlarını yeniden yapılandırmıştır. Özellikle 1980’li yıllardan sonra müşterilerin değerli sayıldığı, satış sonrası desteğin ve ürün garantilerinin devam ettiği yıllar olmuştur. Müşteri ilişkileri işletmelerde rekabet üstünlüğü elde edebilmek için kullanılan önemli araçlardan biri haline gelmiştir (Gümüş, 2002: 134). İkincisi gelişen teknolojik olanaklar ve enformasyon teknolojileri tüm ekonomik alanlarda ve işletmelerde yaygın olarak kullanılmaya başlamıştır. Teknolojik gelişmeler müşteri ile yüzyüze iletişim ihtiyacını ortadan kaldırmıştır. Hızlı iletişim olanaklarının artması işletmelerin telekomünikasyon araçları ile müşteriler ile hızlı ve etkili iletişim kurmasına izin vermektedir. Çağrı merkezleri kuruluşunun da temel mantığını oluşturan bu süreçte müşterilerin işletmelere sınırsız ve kesintisiz ulaşımı amaçlanmaktadır. Üçüncüsü ise; insan kaynakları yönetiminde yaşanan yeni anlayışların değişim mühendisliğine konu olması ve toplam kalite yönetimi, sürekli iyileştirme, performansı yüksek iş sistemleri gibi anlayışların çalışma ilişkilerinde sebep olduğu dönüşümlerdir. Böyle bir ortamda müşterilerle sınırsız ve hızlı iletişimin bir gereği olarak çağrı merkezleri önem kazanmıştır (Man ve Selek Öz, 2009: 82).

Çalışma ilişkilerinde ve bilgi ekonomilerinin gelişiminde gelinen nokta yüksek nitelikte bilgi işçilerine olan talebi arttırmıştır. Ancak bilgi işçilerinin istihdam durumları da "bilgiyi üreten" bilgiyi kullanan" olarak ikiye ayrılabilir. $\mathrm{Bu}$ anlamda bilim adamları, hukukçular ve doktorlar gibi çalışanlar bilgi üreticileri olarak ele alınabilecekken, öğretmenler ve iletişimciler "bilgi iletici ve taşıyıcıları"; idari çalışanlar ve sekretarya "bilgi işleyicilerini”"; donanım ve bakım onarım elemanları ise "altyapı personelini”" oluşturmaktadır (Kandemir ve Karakulle, 2013: 211). İstihdam olanakları incelendiğinde hizmet sektöründe istihdam edilen, veri depolama, veri saklama, sekretarya gibi rutin işlerde çalışan yarı vasıflı işgücünün durumu pek parlak görülmemekte hatta bazı yazarlarca bu işgücü “bilgi işçisi” olarak sayılmamaktadır. Bu işçiler geleneksel tam zamanlı, yasalarla güvence altına alınmış çalışma ilişkilerinden farklı olarak daha belirsiz ve esnek bir çalışma biçimi ile karşı karşıyadırlar (Zaim, 2005: 599-600). 
Çağrı merkezi çalışanları bilgi toplumunda bilgiyi kullanan yeniçağın ara elemanı görünümündedirler. Çağrı merkezleri telefon ve bilgisayar destekli olarak gerçekleştirilen, büyük oranda çalışan ile müşterinin diyaloğuna dayanan, rutine binmiş, düşük vasıf gerektiren bir iş olarak bilgi çağının bilgi işçisi olmayan çalışanlarıdır. Bu işgücü görünümü yükseköğrenim mezunu işsizliği ile aynı işgücü piyasasında buluştuğunda çağrı merkezlerini pazarlık gücü olmayan, kendisine sunulan şartları kabul etmeye mecbur kalmış, dayanabildiği yere kadar dayanan, birkaç sene içerisinde işten ayrılmak zorunda kalan işgücünün çalıştığı mekânlar haline getirmiştir.

Yapılan bazı araştırmalarda çağrı merkezlerinde çalışanların iş tatmininin düşük olduğu (Keser,2006), duygusal tükenmiş̧lik yaşadıkları (Lewig ve Dollard, 2003), çağrı merkezinde çalışmayı geçici bir başlangıç olarak gördükleri ve bir daha çağrı merkezinde çalışmak istemedikleri görülmektedir (Kurt Uğur, 2010, Seçkin ve Ökten, 2016; Yücesan- Özdemir, 2019). Çağr1 merkezlerinde işgücü devir hızının yüksek olması, çalışanların çok genç olması ve bu sektördeki ortalama çalışma sürelerinin kısa olması gibi göstergeler de sektördeki olumsuz çalışma koşullarının varlığını gösterir niteliktedir. Çağrı merkezlerindeki çalışma yaşamı sorunları işin beklentilerin kaynaklanan sorunlar, çalışma sürelerinin uzunluğu, mola sürelerinin kısalığı, vardiyalı çalışma, düşük ücretler, kariyer olanaklarının kısıtlılığ ve sendikalaşma oranlarının düşüklüğü olarak sınıflandırılabilir.

\section{İşin Beklentilerinden Kaynaklanan Sorunlar}

Bazı işletmeler kendi içinde çağrı merkezi oluştururken, bazı işletmeler bu hizmetleri dışardan satın almaktadır. Görüşmeler müşterilerden gelen çağrıların kabul edilmesi (gelen çağrı) ya da çalışanların müşterileri araması (giden çağrı) olarak gerçekleşmektedir. Gelen çağrılarda müşteriler bazı sorun, şikâyet ve önerileri için işletmeyi aramaktadır. Giden çağrılarda ise çalışanlar belirli bir sistematiğe göre satış, pazarlama ya da geri bildirim için müşterileri aramaktadır (Başbuğ vd., 2010: 260). Her iki durumda da çalışanları zorlayan, baskı altına alan durumlar söz konusudur.

Gelen çağrılar büyük oranda sorun yaşayan, problemi olan müşterilerle yapılan görüşmelerden oluşmaktadır. Sistem müşteri memnuniyeti üzerine kurulu olduğundan müşterinin her istediğinde ulaşabileceği ve yardım alabileceği, bekleme süresinin mümkün olan en kısa sürede tutulduğu, 
müşterinin her türlü tepki ve şikâyetini karşılayabilen çalışanlara ihtiyaç duyulmaktadır. Bu sistem müşteri memnuniyeti sağlanırken çalışanların giderek daha zorlu koşullarda çalışma durumunu beraberinde getirmiştir (Çelik, 2016: 1446). Müşteri temsilcileri gün içerisinde pek çok kaba, bağıran hatta hakaret eden müşterilerin sorunlarını ele almakta, müşteri memnuniyeti gereği hepsine karşı kibar ve sabırlı davranmak zorundadır (Keser, 2006: 103).

Giden çağrılar ise genelde hizmet ya da ürün pazarlamak, veri güncellemek, borç takibi gibi konularda çalışanların müşterileri araması şeklinde gerçekleşmektedir (Bulut ve Ataay, 2017: 3-4). Kredi kartı, sigorta ya da cep telefonu operatörlerinin tarifelerini tanıtmak üzere yaptıkları aramalar giden aramalara örnek olarak verilebilir. Giden aramalar bilgisayar tarafından boşta olan müşteri temsilcisine otomatik olarak atanmaktadır. Çağrılar arasındaki sürenin çok kısa olması ve aylık satış hedefleri çalışanlar üzerinde büyük baskı yaratmaktadır. Diğer yandan aranan müşteriler aramalardan rahatsız oldukları için çalışanlara kaba ve kötü davranabilmektedir.

Her iki arama türünde de çalışanların her durumda müşteriyi memnun etmesi, sorununu çözmesi, kendisine ne denilirse denilsin kibar davranma beklentileri çağrı merkezi çalışanlarının en önemli sorunları arasında gösterilebilir. Örgütlerin saygısız hatta küfre varan konuşmaları karşısında bile çalışanlarını korumaması çalışanlarda değersizlik, mutsuzluk ve iş tatminsizliği yaratabilmektedir.

Diğer yandan bilgisayar tarafından otomatik olarak bağlanan çağrılar bir görüşme biter bitmez yenisinin başlaması anlamına gelmektedir. Mola süresi haricinde çalışanın nefes almasına müsaade etmeyen bu sistem pek çok araştırmacı tarafından seri üretim, yürüyen bant sistemine benzetilmektedir (Parlak ve Çetin, 2007: 115; Başbuğ vd., 2010: 261; Doğanay, 2016: 38). Çağrıların yoğunluğunun yanı sıra çağrı merkezindeki koşullar ve işle ilgili beklenti Taylor'un zaman etüdü, standardizasyon, rutine binmiş işler ve yakın denetim gibi özellikleri ile örtüşmektedir. Çalışanların kendilerinden hiçbir şey katamadıkları, duygularını belli edemedikleri, aynı ses tonu ve standart metinlerle yapılan telefon görüşmeleri çalışanları işe yabancılaştırmakta, iş tatminsizliği yaratmaktadır. Fordist ve Taylorist ilkelere olan bu benzerlikler nedeni ile çağrı merkezleri "zihinlere üretim bandı kuran" modern dünyanın fabrikaları olarak betimlenmektedir (Taylor ve Bain, 1999; Başbuğ vd. 2010: 260; Özkan, 2013: 65; Doğanay, 2016: 53; Bulut ve Ataay, 2017: 4-5). 
Çalışanların sürekli hedef tutturma baskısı altında tutulması emek süreci üzerinde yönetimsel bir kontrol ve denetim mekanizması olarak kullanılmaktadır. İşlerin yoğun olduğu zamanlarda bu baskılar artmaktadır. Çalışanlardan çağnıları belli dakikalarda sonlandırmaları ve yeni çağrı almaları beklenmektedir. Bütün çağrıların kayıt altına alınarak çalışanların performans değerlemesi için dinlenmesi çalışanlar üzerinde bir baskı ve gözetim unsuru olarak kullanılmaktadır. Daha iyi kontrol sağlanabilmesi için belli bir metne bağlı olarak konuşma zorunluluğu işleri rutin ve standart bir hale getirmektedir. Yapılan çağrıların belirli süreler içerisinde sonlandırılması ve yeni çağrı alınması baskısı, takım liderlerinin çalışanları sürekli denetleyip gözetlenmesi çağrı merkezlerini zamanın modern Fordist- Taylorist fabrikalarına benzetmeleri haklı çıkarır niteliktedir (Taylor ve Bain, 1999: 115; Grebner vd., 2003: 342; Doğanay, 2016: 39).

Çoğunluğu genç, eğitimli, güzel Türkçe konuşan, plaza çalışanı olarak görülen bu gençler aslında işsiz kalmanın bir alternatifi, sigortalı ve tam zamanlı bir iş bulmanın hatırına yıkıcı ve yıpratıcı çalışma koşullarına razı olmaktadırlar (Çelik, 2016: 1449; Yücesan-Özdemir, 2019: 18). Bir bankanın çağrı merkezinde yapılan çalışmada katılımcıların \% 71,2'si çağrı merkezinde çalışmayı başka bir işe geçmek için bir başlangıç olarak gördüklerini, \% 12,5'i işsiz kaldıkları için bu işi yaptıklarını belirtmişlerdir (Erinç, 2007: 76). Çağrı merkezinden ayrılmış katılımcılarla gerçekleştirilmiş diğer bir çalışmada katılımcıların \% 77'si yeniden firsatları olsa bile tekrar çağrı merkezinde çalışmak istemediklerini ifade etmişlerdir (Kurt Uğur, 2010: 68). Bu sonuçlar çağrı merkezinde çalışmanın gençler için bir ilk adım, işsiz kalmaktansa yapılacak bir iş olarak görüldügünü ortaya koymaktadır.

\section{Çalışma Süreleri, Boş Zaman Kullanımı, Vardiyalı Çalışma ve Fazla Çalışmaya İliş̧kin Sorunlar}

Çağrı merkezi çalışanları 4857 sayılı İş Kanunu'na tabii olarak çalışan işçilerdir. 4857 sayılı İş Kanunu haftalık çalışma süresini 45 saat olarak belirlemiştir. Kanun haftalık 45 saati aşan çalışma süresini ise "fazla çalışma" olarak tanımlamıştır. Ayrıca kanuna göre fazla çalışma yaptırmak için çalışanın onayını almak zorunludur (Çil, 2007: 58). Çağrı merkezlerinde genel olarak tam zamanlı çalışanlar hafta içi günlük dokuz saat çalışarak mesailerini tamamlamaktadırlar. Ancak işlerin yoğun olduğu zamanlarda çalışanların hafta 
sonu mesaiye çağrılmalarına söz konusu olabilmektedir (Parlak ve Çetin, 2007: 118; ÇSGB, 2013: 28- 29; Özkan, 2013: 75; Okur, 2016: 33; Bulut ve Ataay, 2017: 7). Çalışma ve Sosyal Güvenlik Bakanlığı (ÇSGB) tarafından 2013 y1lında gerçekleştirilmiş olan ve daha pek çok araştırmada fazla çalışmalara mesai ücreti ödenmediği ifade edilmiştir (Parlak ve Çetin, 2007: 118; ÇSGB, 2013: 42). Bu durum çağrı merkezlerinin günümüzde yasal olarak işçi çalıştırmakla birlikte karşılığı ödenmeyen fazla çalışmalarla işçinin sömürüldüğünün bir göstergesidir.

Temel özelliği itibari ile bu merkezlerde çalışma haftanın yedi günü yirmi dört saat sürebilmektedir. Müşterilerin her an ulaşabilmesi, sorunlarını ve şikayetlerini hızlı bir biçimde karşılayabilmesi gerekmektedir. Bu durum çağrı merkezlerinde vardiyalı çalışmayı beraberinde getirmektedir. Genel vardiya düzeni gündüz, akşam ve gece şeklindedir. Diğer yandan boş zaman kullanımı çoğunlukla toplam 90 dakikanın kısa sürelerle gün içine paylaştırılması şeklinde gerçekleşmektedir. Çok kısa molalarla gün boyu müşterilerle konuşmak zorunda kalan çalışanların iş yoğunluğuna göre bu sürelerin kısaltılması ya da öğle yemeği süresinin kısa tutulması istenebilmektedir (Parlak ve Çetin, 2007: 126- 127).

Çalışma süresinin artması ile stres ve tükenmişlik düzeyi arasında ilişki olduğu bilinmektedir (Lewig ve Dollard, 2003). Artan çalışma süreleri ve mecburi olarak yaptırılan fazla çalışmalar çalışanları stres ve tükenmiş̧lik duyguları içine sürüklemektedir. Antalya'da 112 çağrı merkezi çalışanları ile gerçekleştirilen çalışmada ortalama çalışma süreleri haftalık 48 saate varan çağrı merkezi çalışanlarının çalışma süreleri ile tükenmişlik düzeyleri arasında ilişki tespit edilmiştir (Turgut, 2014: 69). İstanbul, Bingöl ve Yozgat illerindeki çağrı merkezi çalışanları çalışma yaşamı ile ilgili en önemli sorunlarını "mola sürelerinin yetersiz olması" olarak dile getirmişlerdir (Yücel Tüfekçioğlu, 2015: 76). İngiltere'de çağrı merkezi çalışanları ile gerçekleştirilen diğer bir araştırmada hedeflerin yüksek olması, çağrılar arasında yeterli dinlenme süresi olmaması, zor müşteriler, yönetici baskıları en önemli sorunlar arasında gösterilmiştir (Taylor ve Bain, 2001: 52).

\section{Ücretler, Performans Değerleme ve Kariyer Olanakları}

Çağrı merkezlerinde şef, takım lideri ve müşteri temsilcisi olmak üzere üç hiyerarşik basamak olduğu görülmektedir (Menteşe ve Es, 2017: 28). Müşteri temsilcileri çağrıları alan çalışanlar iken takım liderleri ofis içerisinde müşteri 
temsilcilerini izleyen ve denetleyen, gerekli durumlarda yol gösteren ve performanslarını değerlendiren kişilerdir (ÇSGB, 2003: 16).

Müşteri temsilcileri genel olarak asgari ücretle çalışmaktadırlar. Prim, yemek ücreti vb. yan haklarla ücretler asgari ücretin biraz üzerine çıkabilmektedir. Ücret üzerine alınan primler çalışanların performanslarına göre belirlenmektedir. Prim alabilmek için çalışanlardan yüksek hedefler tutturmaları yanı sıra yüksek bir performans notu almaları beklenmektedir. Performans değerlendirme ise sıklığı, satış ve pazarlama yapılan durumlarda satış hedeflerinin tutturulması, mola sürelerini aşmamak, çağrıların dinlenmesi ve müşteri değerlendirmeleri ile müşteri memnuniyeti, açılış ve kapanış konuşmaları, hızlı hizmet gibi çok yönlü kriterler baz alınarak gerçekleştirilmektedir (Parlak ve Çetin, 2007: 115).

Görüşme metinleri çalışanların kendilerinden hiçbir şey katamayacakları şekilde aşırı bölünmüş, standartlaştırılmış hale getirilerek hem görüşmelerin belli süreler içerisinde bitirilmesi hedeflenmekte hem de görüşmeler elektronik olarak denetlenmektedir. Böylece çalışanların gözetim altında tutulması daha kolaylaşmıştır. Diğer yandan bu kontrollerle performansların yükselmesi hedeflenmektedir (Keser, 2006: 102- 103). Takım liderleri sürekli çalışanları kontrol etmektedir. Çalışanların mola sürelerini ufak tefek aşımları, müşteriyle konuşurken standartın dışına çıkması, hedefleri tutturamaması yanında nitelik olarak da değerlendirme yapılmakta ve çok ufak hatalardan bile performans notları düşürülerek prim kazanmaları engellenmektedir.

Çağrı merkezlerinde çalışan müşteri temsilcilerinin takım liderliği ya da şefliğe yükselebilmelerinin önü açıktır. Bu terfiler performans değerlendirmelerden elde edilen sonuçlar ile kurum içinden sağlanabileceği gibi kurum dışından da seçilebilmektedir. Kurum içi terfiler birkaç sene çalıştıktan sonra başka departmanlara geçiş şeklinde olabileceği gibi kurum tarafından belirlenmiş sınav ve mülakatları geçmek koşuluyla takım liderliğine dikey bir yükseliş şeklinde de olabilmektedir. Başka departmanlara geçen personelin kurum içi çalışanlardan olması firmanın işleyişi ile ilgili bilgi sahibi olması açısından tercih edilmektedir (Seçkin ve Öktem, 2009: 196). Kurum içi dikey yükselişler ise elektronik denetleme sistemi ve çağrıları otomatik olarak müsait çalışana yönlendiren otomatik çağrı dağıtımcısı mekanizmalarından elde edilen verilere göre gerçekleşmektedir. Bu veriler ile dinlenen görüşmelerde ölçülen hizmet kalitesi, hedefleri tutturma gibi kriterler bir arada değerlendirilerek 
çağrı başına performans ölçütlerine göre terfi veya prime hak kazanılmaktadır (Parlak ve Çetin, 2007: 114- 115).

Ancak çağrı merkezlerinde işgücü devrinin çok yüksek olduğu, çalışanların yaş ortalamasının genç olduğu ve çağrı merkezlerinde çalışanların ortalama hizmet yılının 3 yıl olduğu düşünüldüğünde pek çok çalışanın terfi imkanı bulamadığını söylemek mümkündür. Çalışanların pek çoğu çağrı merkezlerinde çalışmayı başka bir işe geçmeden önceki bir basamak olarak görmektedir. Eskiden çağrı merkezinde çalışmış olan katılımcılarla gerçekleştirilmiş bir araştırmada katılımcıların yarısı çağrı merkezinde terfi olanağı bulunmadığını ifade etmişlerdir. Aynı çalışmada katılımcılar bu işte yaratıcılıklarını kullanamadıklarını, ücreti de yeterli bulmadıklarını belirtmişlerdir (Kurt Uğur, 2010: 72- 74). Çeşitli illerdeki çağrı merkezi çalışanlarını kapsayan diğer bir araştırmada Diyarbakır'da çağrı merkezi çalışanları aslında kendi eğitimini aldıkları işlerde çalışmak istediklerini, İstanbul'da çalışanlar ise başka olanakları olsaydı çağrı merkezi dışında bir yerde çalışmak istediklerini ifade etmişlerdir. Ankara'da çalışanlar bu işi kısa süreli bir iş olarak görmektedirler (Seçkin ve Ökten, 2016: 9). Türkiye'de üç farklı bölgeden çağrı merkezi çalışanlarının katıldığı araştırmada da katılımcıların \% 90'1 ücreti yeterli bulmadıklarını belirtmişlerdir (Yücel Tüfekçioğlu, 2015: 74).

\section{İş Sağlı̆̆ı ve Güvenliği}

Çağrı merkezleri iş yükünün çok yoğun olduğu çalışma alanlarıdır. Bu yoğunluktan dolayı çalışanların stres, kronik yorgunluk yaşadığı görülmektedir. Kaba, zorbalık derecesinde saldırgan müşteriler çalışanlarda ayrıca mesleki stres oluşturmaktadır. Çağrıların çok yoğun ve ard arda olması çalışanların uzun süre kulaklık takarak nefes almaksızın konuşmasına neden olmaktadır. Sürekli kulaklıkla konuşmaya bağlı işitme kayıpları, ses teli nodülleri çalışanlarda sık görülen diğer rahatsızlıklardandır. Diğer yandan çalışanların sürekli oturmaya bağlı kas ve iskelet sistemi rahatsızlıkları, mide, bağırsak, dolaşım sistemi hastalıkları yaşadıkları bilinmektedir (Yaşar vd. 2016: 3-4; Törün, 2006: 229- 230). Çağrı merkezlerinde iş sağlığ1 ve güvenliğini tehdit eden diğer bazı faktörler ofis içindeki gürültü düzeyi, 1sı kontrolü, aydınlatma gibi fiziksel etmenler olabilmektedir. Ofis ortamında onlarca çalışanın aynı anda konuşmasına bağlı olarak yaşanan gürültü yorgunluğu mesai sonrası bile çalışanların kulaklarında uğultuya, baş ağrısına neden olmaktadır. 
Çağrı merkezi çalışanları ile gerçekleştirilmiş pek çok çalışmada katılımcıların işlerinden dolayı yaşadıkları sağlık sorunlarından bahsedilmiştir (Parlak ve Çetin, 2007; Kurt Uğur, 2010; Yücel Tüfekçioğlu, 2015; Yücel Tüfekçioğlu, 2015; Akal, 2016; Okur, 2018; Yücesan- Özdemir, 2019). 415 çağrı merkezi çalışanı ile gerçekleştirilen çalışmada katılımcıların maruz kaldıkları radyasyon düzeyi ile nefes darlığı, unutkanlık, çarpıntı, sinirlilik gibi yakınmalar arasında ilişkinin varlığ 1 belirtilmiştir. Ayrıca katılımcıların bel, sırt, boyun ağrısı, işitme sorunları ve yoğun strese yönelik yakınmaları mevcuttur (Akal, 2016). Diğer bir çalışma, 245 çağrı merkezi çalışanı ile gerçekleştirilmiş, katılımcıların \% 70'i bel ağrısı, \% 91'i harcadığı efora göre daha yoğun kronik yorgunluk, \% 72'si gözlerde kuruma, \% 48'i işitme ile ilgili sorunlar, \% 63'ü baş ağrısı, \% 85'i öfke kontrol sorunu yaşadığını belirtmiştir. Aynı çalışmada katılımcıların geleceğe yönelik kaygılar duydukları, işlerinde başarılı olamayacaklarına dair inançlar taşıdığı da görülmüştür (Okur, 2018). İstanbul, Bingöl ve Yozgat illerinden çağrı merkezi çalışanları üzerinde gerçekleşmiş araştırmada katılımcıların en yoğun olarak belirttikleri şikayetler yorgunluk, bağ ağrısı ve boğaz ağrısı iken depresyon risklerinin yüksekliği de dikkat çekmektedir (Yücel Tüfekçioğlu, 2015). Diğer bir çalışmada katılımcıların \% 45,7 'si çağrı merkezinde çalışmaktan dolayı sağlık sorunu yaşadıklarını ifade etmişlerdir (Kurt Uğur, 2010: 69).

Yücesan-Özdemir tarafından Ankara, İstanbul gibi büyük iller yanında Erzincan, Malatya, Uşak, Erzurum, Gümüşhane, Samsun gibi bazı Anadolu illerinde geniş kapsamlı bir araştırma gerçekleştirilmiştir. Araştırmanın sonuçları çağrı merkezlerindeki pek çok sorunu gözler önüne sermektedir. Özellikle katılımcıların iş sağlığı ve güvenliği ile ilgili bazı ifadeleri çağrı merkezlerinde karlılığın işçilerin sağlıklarının önüne geçtiğini gözler önüne sermektedir. Örnekler arasındaki rahatsızlanmasına rağmen çağrılar yoğun gerekçesi ile işyeri hekimi tarafından rapor yazılmayan çalışanın kalp krizi geçirmesi, boğazı konuşamayacak kadar iltihaplı olan çalışana "çağrılar çok yoğun izin veremem" denmesi, kronik kalp hastası olan çalışanın çağrı esnasında fenalaşması üzerine çağrılan takım liderinin gelip ilk iş olarak çalışanın devam eden çağrısını sürdürmesi sektör karlılığın çalışanların sağlığının önünde tutulduğunu gösterir niteliktedir (Yücesan- Özdemir, 2019: 162).

Çağrı merkezlerindeki sağlığı tehdit eden bu ortam, 2012 tarihinde çağrı merkezlerinin "tehlikeli meslekler" kategorisine alınması ile sonuçlanmıştır. 
Böylece çağrı merkezlerinde işyeri hekimi, iş güvenliği uzmanı, diğer sağlık personeli bulundurma süreleri arttırılmıştır. Diğer yandan iş sağlığı ve güvenliği eğitimleri arttırılmıştır. İşe başlayan personelin yaptırması gereken sağlık testlerine ek zorunluluklar getirilmiştir (Tartanoğlu, 2014: 114). 2013 yılında ÇSGB tarafindan bir komisyon oluşturulmuş ve hazırladıkları raporda çağrı merkezleri iş kazası ve ölüm oranının yüksek olduğu işler kategorisine alınmıştır. Ancak bu düzenleme 2017 yılında sektördeki şirketlerin baskısı ile geri çekilmiştir (Yücesan-Özdemir, 2019: 149).

\section{Sendikalaşma Ĕğilimleri}

Teknolojik gelişmeler, yeni çalışma biçimlerinin ortaya çıkması, beyin gücünün daha ağırlıklı kullanılması gibi nedenler istihdamın sektörel dağılımında hizmet sektörünün ağırlığını arttırmaktadır. Hizmetler sektörü ile birlikte beyaz yakalı işgücünün istihdamı artmakta, esnek çalışma biçimlerinin yaygınlaşması, kadın istihdamındaki artış ile birlikte sendikalaşma oranlarında düşüş yaşanmaktadır. Beyaz yakalı işgücü mavi yakalılara göre daha yüksek pazarlık gücüne sahip olduğundan toplu pazarlık yerine bireysel pazarlık olanaklarını tercih etmektedir (Yorgun, 2005: 144). Çağrı merkezleri esnek çalışma modellerinin uygulandığı bir sektör olarak diğer çalışma alanlarına göre sendikalaşma oranlarının düşük olduğu bir sektördür. Diğer yandan 2000'li yıllara kadar çeşitli işkollarına giren çağrı merkezi çalışanlarının özel bir sendikaları olmaması örgütlenmeleri önünde bir engel teşkil etmekteydi. 2012 yılından sonra "7 No'lu İletişim İşkolu” tanımlanması ile çağrı merkezi çalışanlarının örgütlenebileceği işkolu belirlenmiş ve sendikalaşma önündeki önemli bir engel kaldırılmıştır (Menteşe ve Es, 2017: 31- 32).

Yasal engellerin kaldırılmış olmasına rağmen çağrı merkezi çalışanları arasında sendikalaşma oranlarının düşük seyrettiği görülmektedir. Çağrı merkezi çalışanları eğitimli, ofis çalışanı olmaları nedeniyle beyaz yakalı çalışan görünümü taşımakla birlikte çalışma koşulları incelendiğinde beyaz yakalı çalışanların pek çok avantajını yaşayamamaktadır. Yaptıkları işin yükssek nitelik gerektirmemesi pazarlık güçlerini düşürmektedir. Bu durum çağrı merkezi çalışanlarını sendikalaşma eğilimleri düşük, bireysel pazarlık talebinde olan ve sendikalara antipati duyan "beyaz yakalı prototipinden” farklı bir görünüm sergilemektedir (Baştürk vd. 2011: 155). Yapılan çalışmalarda çağrı merkezleri çalışanlarının sendikalara karşı olmadıkları ama işgücü devir oranlarının yüksek 
olması, çalışma sürelerinin genel olarak kısa olması, meslektaşlarından tepki görme korkusu gibi sebeplerle sendikalaşmaya soğuk yaklaştıkları görülmektedir (Taylor ve Bain, 2001: 56- 57).

Esasen çağrı merkezlerinde yaşanan sorunların çözümünde sendikalar önemli rol oynayabilecektir. Çağrı merkezlerinde sendikalaşma oranlarının ve Bain tarafından gerçekleştirilen araştırmada 119 çağrı merkezinde sendikalaşma oranlarının yüzde 50'ye yaklaştığı ve ücret, çalışma saatleri, fazla mesailer ve tatiller gibi konuların toplu pazarlığa konu olduğu görülmüştür. Diğer yandan sendikaların çağrı merkezlerinde en önemli sorunları arasında olan boş zaman kullanımı, çalışanların gözetim altında tutulması, kahve molaları ve analık izni gibi bazı konularda haklar elde ettiği belirtilmiştir (Taylor ve Bain, 1999: 113114). Çalışanların sendikal bilincinin arttırılması, sendikaların da çağrı merkezlerindeki bu hak arama boşluğunu görerek buralarda sendikal oranları arttırmak için özel çaba sarf etmeleri büyük önem taşımaktadır.

\section{Araştırmanın Amacı}

İşletmeler kendi çağrı merkezleri ile hizmet vermek yanında kurumsal firmalardan bu konuda hizmet de alabilmektedir. Pek çok sektörde çağrı merkezi hizmetlerinin başka işletmelerden sağlandığı bilinmektedir. Kurumsal olarak çağrı merkezlerinin yoğunlukla kullanıldığı sektörlerden biri bankacılık sektörüdür. Bankalar gelen aramalarla bireysel müşteri işlemleri gerçekleştirip, sorunları çözmeye çalışırken, giden aramalarla da tahsilat, kredi kartı ve sigorta pazarlamaktadır. Literatürde gelen arama alan müşteri temsilcilerinin sorunlarına yönelik araştırmalar mevcuttur. Giden arama yapan müşteri temsilcilerine yönelik özel bir araştırma bulunmamaktadır. Giden arama yapan müşteri temsilcilerinin "beklemedikleri bir anda müşteriyi aramalarından" ve "satış baskısı yaşamalarından” kaynaklanan kendine özgü zorlukları olduğu düşünülmektedir. Bu nedenle bu çalışmanın amac1 "giden arama” yapan müşteri temsilcilerinin yaşadıkları sorunların belirlenmesidir.

\section{Araştırmanın Yöntemi}

\section{Araştırmanın Evreni ve Çalışma Grubu;}

Bu araştırmanın evreni Türkiye'de istihdam halinde olan 107 bin müşteri temsilcisidir. Evreni temsil etmek üzere "kolay ulaşılabilir örneklem" yöntemi 
ile çalışma grubu belirlenmiştir. Bu örnekleme yöntemi araştırmalara hız ve pratiklik kazandırmaktadır. Araştırmacı bu yöntemde ulaşılması kolay ve yakın bir durumu seçmektedir (Yıldırım ve Şimşek, 2016: 123).

Bu çerçevede Türkiye'de 14 şube, 12 binden fazla çalışanı ile finans, kamu, enerji, telekomünikasyon, yerel yönetim ve e-ticaret sektörlerinde çağrı merkezi hizmeti veren bir şirketin banka (giden arama) ekibi Bursa ofisi çalışma grubu olarak seçilmiştir. Zaman ve maliyet kısıtları nedeni ile çalışma Bursa ili ve "x bankası" çalışanları ile sınırlandırılmıştır. Araştırmaya müşteri temsilcileri dahil edilmiş, yönetici grubundaki takım lideri ve şefler kapsam dışı bırakılmıştır. Araştırmanın kapsamı giden arama yapan müşteri temsilcileridir. Toplamda 12 müşteri temsilcisi ile görüşme hedeflenmiş, yanıtların tekrara düştügüünün görülmesi üzerine görüşmeler 10 'da sonlandırılmıştır.

\section{Araştırmanın Deseni ve Soruları}

Çalışmada nitel araştırma desenlerinden olgubilim kullanılmıştır. Olgubilim, bize tam anlamiyla yabancı olmayan, diğer yandan tam anlamıyla kavrayamadığımız, derinlemesine bir anlayışla sahip olmadığımız olguları açıklamak için kullanılır (Yıldırım ve Şimşek, 2016: 69). Bu çalışmalardaki temel amaç bir olgu (fenomen) ile ilgili bireysel deneyimlerin genelleştirilmesidir. $\mathrm{Bu}$ amaçla bireysel algılar ortaya çıkarılarak yorumlamak ve genellemek hedeflenmektedir (Karademir vd., 2017: 56). Bu araştırmada giden arama yapan müşteri temsilcilerinin çalışma yaşamında karşılaştıkları sorunlara yönelik deneyimleri detaylıca incelenmeye çalışılmıştır. Katılımcıların karşılaştıkları sorunlar kendi deneyimleri ile ortaya çıkarılması amaçlandığı için bu desen tercih edilmiştir.

$\mathrm{Bu}$ çerçevede araştırmada aşağıdaki sorulara yanıt aranmıştır;

Araştırma Sorusu 1) Müşteri temsilcilerinin karşılaştıkları sorunlar nelerdir?

Araştırma Sorusu 2) Giden arama yapan müşteri temsilcilerinin yaşadıkları sorunlar gelen arama yapan müşteri temsilcilerinden farklılık göstermekte midir?

Veri toplama aracı olarak "görüşme" yöntemi belirlenmiştir. Görüşme 20. yüzyılın son çeyreğinde sosyal bilimlerde sıklıkla kullanılan yöntemlerden biridir. Görüşme yöntemince önceden belirlenmiş ve ciddi bir amaca yönelik hazırlanmış sorular karşılıklı etkileşim ve iletişim sürecinde yanıtlanmaktadır. Böylece 
yanıtlayıcının iç dünyasına girerek deneyimleri, tutumları, niyetleri, yorum ve tepkileri belirlenmeye çalışılmaktadır (Yıldırım ve Şimşek, 2016: 129- 130).

Görüşmede sorular yarı yapılandırılmış görüşme formu ile katılımcılara sorulmuştur. Soru hazırlama aşamasında önce detaylı bir literatür taraması yapılmıştır. Konuyla ilgili yerli ve yabancı literatür taranarak çağrı merkezinde çalışanların yaşadığ 1 sorunlara yönelik bir soru havuzu oluşturulmuştur. Soru havuzu sosyal politika alanında çalışan iki öğretim üyesi ve çağrı merkezinde çalışan bir yüksek lisans öğrencisine sunulmuş, katkıları ve yorumları alınmıştır. Daha sonra araştırmacı tarafından soru havuzundan sorular seçilerek görüşme formu sadeleştirilmiştir. Görüşme formunun sade hali yeniden öğretim üyelerinin ve çağrı merkezi çalışanı yüksek lisans öğrencisinin görüşüne sunulmuştur. Fikir birliği sağlanması üzerine görüşme formu ile iki çağrı merkezi çalışanı ile pilot görüşme gerçekleştirilmiştir. Pilot görüşmeler sırasında gerekli görülen ufak değişiklikler de yapılarak görüşme formuna son şekli verilmiştir.

Görüşmeler 25 Ekim- 20 Kasım 2019 tarihleri arasında müşteri temsilcileri ile alınan randevular ile hafta sonları ve resmi tatil günlerinde gerçekleştirilmiştir. Görüşmeden önce görüşme formu katılımcılara mail ile gönderilmiş ve incelemelerine firsat verilmiştir. Görüşmeler esnasında öncelikle çalışmanın amacı hakkında katılımcılara bilgi verilmiş, ses kaydı alınması için izin alınmış ve isimlerinin hiçbir yerde geçmeyeceği bilgisi verilmiştir. Daha sonra görüşmelere başlanmıştır. En uzun görüşme 1 saat 10 dakika, en kısa görüşme 48 dakika sürmüş̧ür.

Görüşmelerden elde edilen verilen MAXQDAAnalytics Pro 2020 nitel analiz programı aracılığı ile analize tabi tutulmuştur. Öncelikle görüşmelerin ses kayıtları deşifre edilerek Microsoft Office Word programına aktarılmıştır. Doküman haline getirilen görüşmelerden araştırmacı tarafından tema ve alt kodlar oluşturulmuştur. Uzman iki öğretim üyesi de dokümanlara yönelik tema ve alt kodlar belirlemiştir. Araştırmacının ve öğretim üyelerinin kodları karşılaştırılarak görüş birliği sağlanmıştır.

\section{Araştırmanın Bulguları}

Görüşmeye 10 müşteri temsilcisi katılmıştır. 3 erkek, 7 kadın katılımcının yaşları 24 ila 41 arasında değişmektedir. En deneyimli katılımcı 3 yıldır, en deneyimsiz katılımcı 6 aydır çağrı merkezinde çalışmaktadır. Ayrıntılar Tablo 1'de verilmiştir. 
Tablo 1

Katılimcilara Ait Demografik Bulgular

\begin{tabular}{|c|c|c|c|c|c|c|}
\hline & Cinsiyet & Yaş & $\begin{array}{l}\text { Medeni } \\
\text { Durum }\end{array}$ & $\begin{array}{c}\text { Eğitim } \\
\text { Durumu }\end{array}$ & $\begin{array}{l}\text { Çalışma } \\
\text { Süresi }\end{array}$ & $\begin{array}{l}\text { Önceki İş } \\
\text { Deneyimi }\end{array}$ \\
\hline 1 & $\mathrm{~K}$ & 36 & Evli & İktisat & 2 Yil & 13 Y1l Fabrika \\
\hline 2 & K & 29 & Evli & $\begin{array}{l}\text { Çalışma Ekono- } \\
\text { misi ve Endüstri } \\
\text { İlişkileri }\end{array}$ & $10 \mathrm{Ay}$ & $\begin{array}{l}4 \text { Yıl AVM Satış } \\
\text { Temsilcisi }\end{array}$ \\
\hline 3 & K & 25 & Evli & İstatistik & $1 Y_{11}$ & Yok \\
\hline 4 & K & 27 & Bekar & Lise & $2 Y_{11}$ & $\begin{array}{c}4 \text { Yı1 AVM Satış } \\
\text { Temsilcisi }\end{array}$ \\
\hline 5 & $\mathrm{E}$ & 25 & Bekar & $\begin{array}{l}\text { Radyo ve Tel- } \\
\text { evizyon }\end{array}$ & $1.5 \mathrm{Y} 1 \mathrm{l}$ & Yok \\
\hline 6 & K & 28 & Bekar & Gazetecilik & $3 Y_{11}$ & 2 Yıl Çağrı Merkezi \\
\hline 7 & K & 41 & Bekar & İktisat & 6 Ay & 9 Yil Otomotiv \\
\hline 8 & $\mathrm{E}$ & 27 & Bekar & Arkeoloji & $1 Y_{1} 1$ & $\begin{array}{l}2 \text { Y1l İnternet } \\
\text { Bağlama }\end{array}$ \\
\hline 9 & K & 26 & Evli & Lise & $2 Y_{11}$ & $\begin{array}{l}1 \text { Yıl Hastane } \\
\text { Danışman }\end{array}$ \\
\hline 10 & E & 24 & Bekar & Lise & $2 Y_{11}$ & 3 Y1l Reklamcilik \\
\hline
\end{tabular}

Katılımcıların 8'i 30 yaşın altında olup 7 tanesi lisans mezunudur. Üç katılımcının ilk çalışma yeri çağrı merkezi iken diğerlerinin başka sektörlerde iş deneyimine sahiptir. Araştırmada çağrı merkezinde müşteri temsilcisi olarak çalışanların sorunlarına yönelik 6 tema ve 23 alt kod belirlenmiştir. Temalar Şekil 1'de gösterilmiştir.

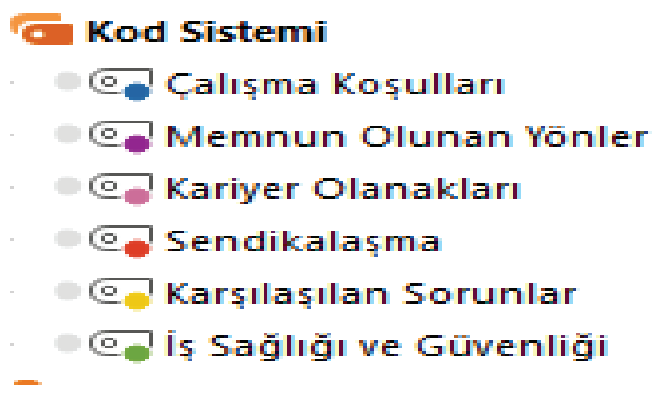

Şekil 1. Tema ve Alt Kodlara İlişkin Kod Matrisi

\section{Çalışma Koşulları Temasına İlişkin Bulgular}

Temalar ayrı ayrı değerlendirildiğinde çalışma koşulları teması altında 5 alt kod belirlenmiştir. Bu alt kodlar arasında katılımcıların en yoğun olarak değindikleri konu ücret ve prime ilişkin sorunlar olmuştur. Katılımcıların verdikleri yanıtların frekansları Şekil 2'de verilmiştir. 


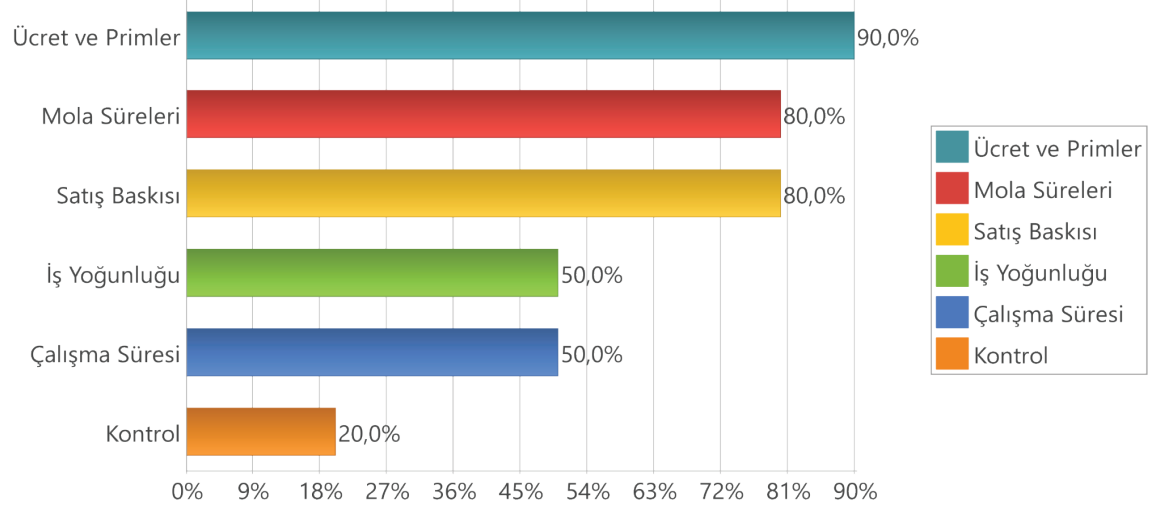

Şekil 2. Çalışma Koşulları Teması Alt Kodlarına İlişkin Frekanslar

Katılımcıların değindikleri konuların başında \% 90 ile ücret ve primle ilgili sorunlar gelmiştir. Katılımcıların tamamı asgari ücretle çalışmakta ve yaptıkları iş karşılığında aldıkları ücretin çok düşük kaldığını belirtmektedirler. Ücretler yanında prim sistemi de olmakla birlikte katılımcılar prim almanın güçlüğünü, prim verilmemek için çaba gösterildiğini ve prim hesaplama sistemine karşı güvensizliklerini dile getirmişlerdir. Konula ilgili bazı katılımcı ifadeleri şu şekildedir;

"Prim oranı çalışmamıza çok düşük. Bence prim hesaplamalarında bir şey var, yanllş hesaplyyorlar bence... " $K 1$.

“Prim hakedişlerimiz söylenenin altında ..." K3.

"Yani 100-150 TL gibi bir prim düşüyor, çok yetersiz, bu performansa göre çok yetersiz..." K7.

"Prim usulü ile çalışlyoruz ama prim vermemek için her yolu deniyorlar...” K8.

Araştırmada \% 80 oranında değinilen sorunlardan biri de yoğun çalışmalara karş1lık verilen mola süreleridir. Katılımcıların tamamı saat başına 10'ar dakika, ve yarım saat yemek molasına sahiptir. Elli dakika görüşme döngüsünden sonra 10 dakika mola süresinin çok yetersiz olduğu dile getirilmiştir. Çağrıların otomatik dağıtım sistemi ile bağlanmasından dolayı çok sık aralıklarla çağrı alınmakta ve çalışanlar molalar dışındaki zamanlarının neredeyse tamamını 
müşteri görüşmelerinde geçirmektedirler. Diğer yandan yarım saatlik yemek molalarının yetersizliği de dile getirilmektedir. Konuya ilişkin katılımcı ifadelerinden bazıları şu şekildedir.

"Sürekli konuştuğumuz için konuşmamak dinlenmek istiyoruz, yetmiyor yani 10 dakika...” K1.

"Tuvalet falan mola hakkında gidiyor, o 10 dakikayı aşmayacaksın..." K2.

"Yarım saat yemek, gerisi 10'ar dakika, hızlandırılmış sisteme sokuyor, çok klsa yetmiyor" $\mathrm{K} 4$.

"Yemek molasında ancak yukarı çıkıp yiyip inebiliyorsun, başka bir şeye vakit kalmuyor, 10 dakikalarda bir şey yapılmıyor ...” K9.

$\mathrm{Bu}$ araştırmada elde edilen sonuçlar çağrı merkezindeki ard arda otomatik olarak bağlanan çağrıların "seri üretim, yürüyen bant", Fordis- Taylorist- Fordist üretim süreci (Taylor ve Bain, 1999; Parlak ve Çetin, 2007: 115; Başbuğ vd. 2010: 260; Özkan, 2013: 65; Doğanay, 2016: 53; Bulut ve Ataay, 2017: 4-5) ve "üçüncü bin y1lın fabrikaları" (Yücesan- Özdemir, 2019: 199) benzetmelerini onaylar biçimdedir. Katılımcı (7) tarafindan ifade edilen "robot gibi oluyorsun" ifadesi çalışanların ne kadar tek düze, hızlı, kendinden bir şey katamadan ve düşünemeden iş yapmak durumunda kaldıklarını ifade etmektedir.

Mola süreleri ile aynı oranda vurgulanan diğer bir konu da satış baskısıdır. Müşteri temsilcileri sürekli satış baskısı altında olduklarını, her ay yüksek hedefler verildiği, hedefi tutturduğunda ise takdir edilmedikleri gibi daha yüksek hedefle karşılaştıklarını belirtmektedirler. Konuyla ilgili katılımcıların ifadelerinden bazıları şu şekildedir;

"Yöneticilerimiz, takım liderimiz bize sürekli psikolojik baskl uyguluyorlar. "yap, yapmalısın, daha yüksek, daha çok verimlilik", insan psikolojik baskı altında hissediyor..." K9.

"Verdiğin hizmetle ilgili sana o kadar çok baskı geliyor ki, yöneticin sana günde 10 kere aynı konuda mail atıyor, psikolojik baskl... aylık hedefler veriliyor, biz tutturuyoruz zor da olsa başarlyoruz, o gün hemen gün içinde yeni hedef veriliyor " K10. 
Çağrı merkezlerindeki diğer önemli bir çalışma yaşamı sorunu iş yoğunluğudur. Sektörde çalışma prensibi boşta olan müşteri temsilcilerine otomatik bilgisayar sistemi tarafından çağrı bağlandığı için çalışanın telefonu kapanır kapanmaz yeni bir çağrı bağlanmaktadır. Katılımcı 2 tarafından dile getirilen "10 saniye geçmeden yeni bir çağrı alıyorsun” ifadesi müşteri temsilcilerinin mola süreleri dışında hiç dinlenme firsatı bulamadan yeniden görüşmeye başladıklarını göstermektedir.

Haftalık 45 saat üzerinden sözleşmeleri yapılmış olan çalışanların satış hedeflerini tutturamadıklarında haftasonu da çalıştıkları görülmektedir. Haftasonu çalışmaları fazla çalışmadan sayılmamakta ve mesai ücreti ödenmemektedir. Konuyla ilgili katılımcı ifadeleri şu şekildedir;

"Bizi haftasonu çağırırlarsa, gel satışların düşük derlerse o fazla çalışma sayılmıyor” $K 2$.

"Hedef tutmama nedeni ile haftasonu çağrllabiliyoruz. Haftasonu için fazla çalışma ücreti yatırılmıyor” $\mathrm{K}$.

Çağrı merkezlerinde haftasonları fazla çalışma yaptırıldığı ve bu fazla çalışmalara ücret ödenmediği ÇSGB'nın raporu da olmak üzere pek çok çalışmada belirtilmektedir (ÇSGB, 2013: 42; Parlak ve Çetin, 2007: 126- 127). ÇSGB'nın raporu 2013 yılında yayınlanmasına rağmen 2020 yılında gerçekleştirilen bu araştırmada aynı sorunun dile getirilmesi sektörde bu konuda bir düzenleme ve denetleme yapılmadığını düşündürür niteliktedir.

Çalışma koşulları temasının son alt kodu "kontroldür". Çağnı merkezi ile ilgili yapılan çalışmalarda çalışanların Taylorist ilkelere benzer şekilde sıkı bir denetim ve kontrol altında oldukları belirtilmektedir (Taylor ve Bain, 1999: 115; Grebner vd., 2003: 342; Doğanay, 2016: 39). Bu araştırmada da katılımcıların benzer söylemleri mevcuttur. Katılımcılar görüşmeler arasında birkaç dakikalığına bilgisayarlarını "meşgul” konumuna getirerek çağrı almadıklarında bilgisayarların sinyal verdiğini ve takım liderlerinin gelip kontrol ettiğini belirtmektedirler. Diğer yandan takım liderleri gün içerisinde sürekli olarak müşteri temsilcilerini kontrol etmektedir. Ayrıca çağrılar kayıt altına alınarak dinlenmekte ve bu şekilde de müşteri temsilcilerinin her yaptıkları sıkı bir denetim altında tutulmaktadır. Konuyla ilgili bazı katılımeı ifadeleri şu şekildedir; 
"Takım lideri gelip kontrol ediyor ve çağrı gelmiyor mu diye ekrana baklyor ve hemen düzeltiyor" $K 2$.

"İ̧yerimiz çok disiplinli, kameralar olduğu için sürekli gözlem altındayız" $\mathrm{K} 9$.

Kaydedilen ve belirli dakikada bitirilmesi gereken, rutin metinlere bağl1 görüşmeler denetimin kolaylaşmasını sağlamaktadır. Sektördeki çalışma şeklinin Taylorist ilkelere benzetilmesi bu örneklerle de desteklenmektedir. Bu araştırmada da diğer araştırmalara benzer şekilde yoğun bir baskı oluşturan denetimin söz konusu olduğu görülmektedir (Taylor ve Bain, 1999; Doğanay, 2016; Başbuğ vd. 2010; Özkan, 2013; Bulut ve Ataay, 2017; Yücesan- Özdemir, 2019).

\section{Karşılaşılan Sorunlar Temasına İlişkin Sonuçlar}

Müşteri temsilcilerinin karşılaştıkları en önemli sorunlar arasında müşteri ve yöneticiler ile ilgili sorunlar yer almaktadır. Katılımcıların alt kodlara ilişkin frekansları Şekil 3'de verilmiştir.

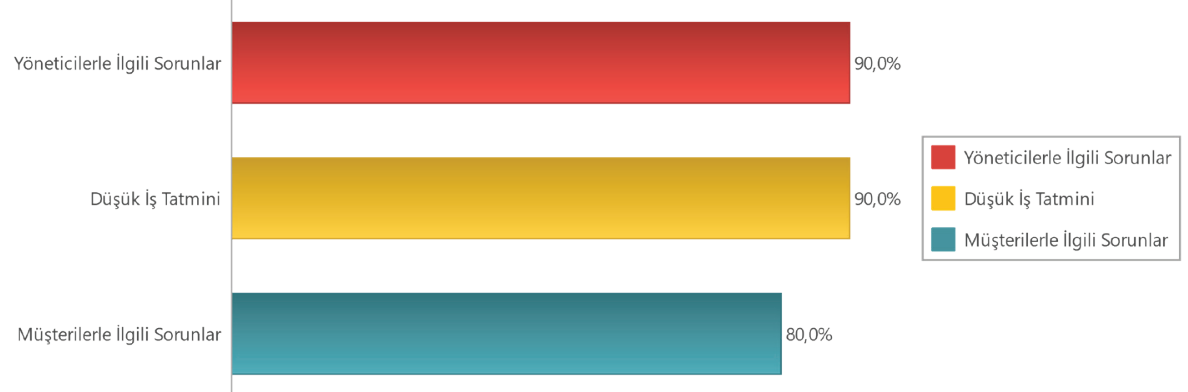

Şekil 3. Karşılaş1lan Sorunlar Teması Alt Kodlarına İlişkin Frekanslar

Katılımcıların \% 90 oranında yoğunlukla vurguladıkları sorunlar yöneticilerle ilgili sorunlar ve düşük iş tatmini olmuştur. Genel olarak katılımcılar yöneticilerinin yaşanan problemleri çözmedikleri, kendilerine karşı sert oldukları, en ufak bir hatada bile sert ya da yazılı uyarı verdikleri ve genelde kurum dışından geldikleri için bazı işleyiş sorunlarına hakim olmadıklarını belirtmektedirler. Katılımcıların konuya ilişkin bazı ifadeleri şu şekildedir; 
"Takım lideri ile sorun yaşlyorum. Bizi sürekli kenara çekiyor, tahsilatın az, satışın az. Bu da bizi olumsuz etkiliyor. Olumlu yönde yaklaşma yok” $\mathrm{K} 1$.

"Yöneticiler görmezden geliyor, içinde olduğun sorunları çözmüyorlar. Performansindaki iki aylık başarısızlı̆̆ görmezden gelmiyor hemen yasal uyarlyı bastyor. Savunma yazlyorsun” K2.

"Yöneticiyi memnun edemiyorsun, sen emek vermişsin istediği skalaya çok yaklaşmışsın, bunun bir tebriki yok” $\mathrm{K} 4$.

"Sana karşı yaklaşımları olumlu olmuyor. Problem yaşıyorsun. Her ne kadar "büyük şirketiz empati yapıyoruz" deseler de seni düşünen kimse yok. Senin tamamen üretimine baklyorlar” K8.

İş yoğunluğu, müşteri ve yöneticilerle yaşanan sorunlar bireylerde iş tatminini düşürmektedir. Katılımcıların \% 90 oranında değindikleri konular arasında yaptıkları işten mutlu olmadıkları ve daha iyi bir iş buldukları anda başka bir işe geçmek istedikleri görülmektedir. Bazı katılımcı ifadeleri şu şekildedir;

\author{
"Birçok insanla karşılaşıyorsun. Hepsine anlat anlat artık \\ boğuluyorsun" $K 4$. \\ "Çok fazla personel dönüşümü olduğu için kendini değerli \\ hissettirmiyorlar" $K 7$. \\ “Aynı ücrete farklı iş bulsam bir dakika düşünmem” K8. \\ "Yaşadiğımız sorunlardan dolayı işten soğuma olabiliyor" $\mathrm{K} 9$.
}

Günün önemli bir saatinde müşterilerle iletişim kuran çalışanlar iletişim kuramadıkları, kendilerine sert ve kaba davranan, onların ifadesi ile "insan olduklarını unutan” tavırlarla işini yapmaya çalışan müşteri temsilcilerini zor bir duruma sokmaktadır. Bu konuda yoğunlaşan yanıtların oranı \% 80'dir. Müşterilerle ilgili yaşanan sorunlar çalışanların stres düzeyini arttırmakla kalmayıp düşük performans notu almasına da neden olmaktadır. performans notlarının düşmesi doğrudan prim oranlarına yansımaktadır. Katılımcıların duruma ilişkin bazı ifadeleri şu şekildedir; 
"Müşterilerin bize aşırı tepkili olması en büyük sorun. Müşteri bize

küfür ediyor, bağırıyor biz hiçbirşey diyemiyoruz” $K 2$.

“Görüş̧ü̆̈̈̈n müş̧teriler senin insan olduğunu unutuyorlar” K8.

Çağrı merkezlerinde gelen aramalarda genelde sorun bildirmek üzere arayan müşteriler, giden aramalarda ise aranmaktan şikayet eden müşteriler çalışanlara sert hatta kabalık sınırlarını aşan tavırlarda bulunabilmektedir. Karşılaşılan sorunlar arasında katılımcıların "kriz müşteri” ifadesi ile tanımladığı bu müşteri tipi, çalışanları strese sokmakta, motivasyonlarını düşürmekte hatta iş tatminlerini azaltmaktadır (Keser, 2006; Çelik, 2016).

\section{Kariyer Olanakları Temasına İlişkin Sonuçlar}

Çağrı merkezleri ile ilgili olumsuz durumlardan bir diğeri kariyer olanaklarının sınırlılığıdır. Müşteri temsilcisi olarak işe başlayan gençlerin yükselme alternatifleri takım lideri ve şef poziyonlarıdır. Katılımcılar bu olanakların kendilerine sunulduğunu ancak yükselmenin mümkün olmadığını, kurum içinden yülseltmeler yerine kurum dışından atamaların yapıldığını belirtmektedirler. Yükselme kriterlerinin belirsizliği ve liyakat sorunu vurgulanan diğer noktalardır. Alt kodlara ilişkin frekanslar Şekil 4'de verilmiştir.

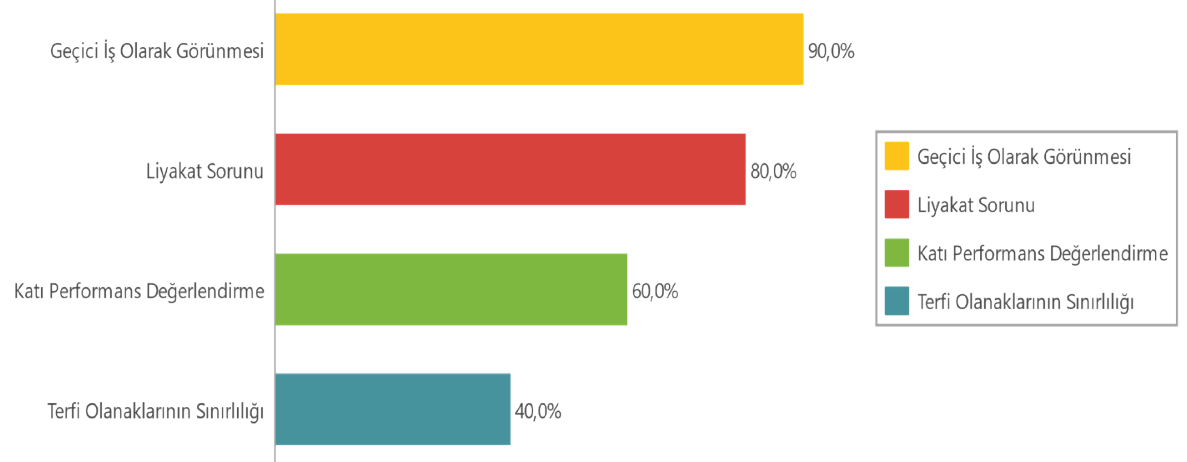

Şekil 4. Kariyer Olanakları Teması Alt Kodlarına İlişsin Frekanslar

Çağrı merkezleri yoğunlukla gençlerin çalıştığı bir sektör olarak görülmektedir. Belirli bir nitelik gerektirmediği için günümüzde lise mezunu ya da üniversiteden yeni mezun olmuş gençlerin tercih ettikleri iş olanağı haline gelmiştir. Ancak yapılan görüşmelerde katılımcıların bu zorlu çalışma koşullarında çağrı merkezlerini emekliliğe kadar giden bir kariyer yolu olarak görmedikleri 
belirlenmiştir. "Bu işi başkasına tavsiye eder misiniz?" sorusuna katılımcıların 9 tanesi "işsizlerse, başka alternatifleri yoksa ederim, yoksa etmem" şeklinde yanıt vererek müşteri temsilciliğinin geçici bir iş olarak yapıbilecek bir meslek olduğunu belirtmişlerdir. Katılımcıların \% 80 yoğunlukla değindikleri diğer bir konu da terfilerde liyakat sorunudur. Çalışanlar kendilerine terfi olanakları olduğu söylendiği ancak belirtilen kriterlere uysalar bile atamaların dışarıdan yapıldını ifade etmişlerdir. Konuyla ilgili bazı ifadeler şu şekildedir;

"Şeffaf diyorlar ama bence kadro açılınca yeri belli" K2.

"Neye göre alındiğını hala anlamadım. Maddeler var ve bu maddelere uyduğunu düşünüyorsun. Ama senin karşına farklı şekillerde geliyorlar ya da aldıkları insanlara baktı̆̆ında o maddelerle bă̆daşmıyor" $K 4$.

"Torpil gerekiyor bana göre, torpil olunca da çok basamak atlamana gerek olduğunu düşünmüyorum ama torpilsiz mümkün değil” K7.

Terfi ile ilgili değinilen diğer bir konu da performans değerlendirme kriterlerinin katılığıdır. Verilen yanıtlar arasında konunun yoğunluğu \% 60’dır. Performans değerlendirme hem prim ödemeleri hem de terfiler için belirleyici olmaktadır. Katılımcılar yüksek çaba ve performans gösterdiklerini ancak en küçük hatalarda bile performans notlarının kırıldığını ifade etmektediler. Üstün performans gösterip yüksek hedeflere ulaşılsa bile alınan takdir ve prim düşük olmakta ayrıca daha yüksek hedeflerle çalışanların motivasyonu kırılmaktadır. Sektörün kariyer ile ilgili bir sıkıntısı da kariyer yollarının sınırlılı̆̆ıdır.

"Hedeflere ulaşmak için beklenenler çok fazla. Çağrı süren 3 dakikayı geçmeyecek, molan 10 dakikayı geçmeyecek, aşınca hemen puan kırllıyor. Mola aşımlarında çok ciddi sorunlar olabiliyor. Sinirli müşteri telefonu suratımıza kapatıyor, bazı şeyleri söylemedik diye bizden puan kirlyorlar'K10.

"Çok saçma hedefler veriyorlar. Satışı yapsan bile mersis numarasını en başta söylemedin diye puan kırlyorlar. Performans notun yüksek olacakken yaptı̆̆ın satıştan sonra bile ortaya düşüyor” $K 2$.

"Her müşterinin konuşması, tavrı farklı oluyor. Ama verdikleri değerlendirme formunda aynı ölçüyü kullanıyorlar. Bazı çağrılarda esneklik olmall, çok sinirli müşteri olduğu zaman sen ona müşteri 
temsilcisi numaranı bile aktaramıyorsun. Aktaramadığın için puan kirllyyor" $K 4$.

\section{İşS Sağlı̆̆ı ve Güvenliği Temasına İlişkin Sonuçlar}

Yapılan görüşmelerde katılımcıların çok yoğun olarak vurguladıkları noktalardan bir diğeri de çalışma koşullarına ve çalışma ortamındaki 1sı, 1şık, koltuklar ve bilgisayar ekranlarına bağlı olarak yaşanan sağlık sorunlarıdır. Katılımcıların tamamı çağrı merkezinde çalışmaya başladıktan sonra meydana gelen sağlık sorunlarından bahsetmiştir. Yanıtlara ilişkin frekanslar Şekil 5'de verilmiştir.

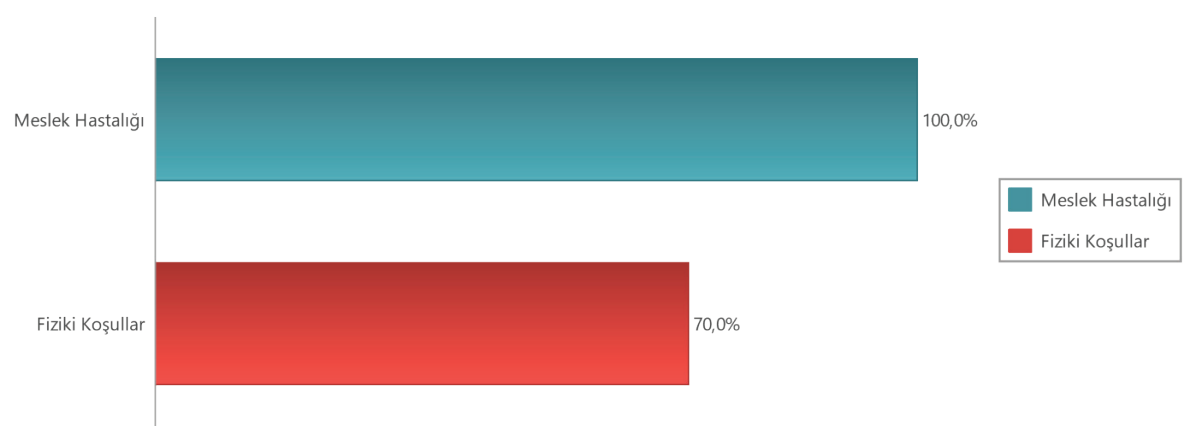

Şekil 5. İş Sağlığı ve Güvenliği Teması Alt Kodlarına İlişkin Frekanslar

Araştırmada katılımcıların tamamı (\% 100) çağrı merkezinde çalışmaktan dolayı yaşadıkları sağlık sorunlarından bahsetmiştir. En çok değinilen sağlık sorunu kulakla ilgili sağlık sorunlarıdır. Daha sonra ses ve boğaz sorunları, göz rahatsızlığı ve bel ağrılarına vurgu yapılmıştır. Katılımcılar kulaklık takarak telefonla konuşmakta olduklarından kulaklığın takılı olduğu taraftaki kulaklarında işitme kaybı, kulak ağrısı ve çınlamasından bahsetmişlerdir. Diğer yandan uzun süreli konuşmaktan ses teli iltihabı, boğaz ağrısı yoğunluklu olarak dile getirilen diğer sağlık sorunları arasındadır. Gün boyu ekrana bakmaktan göz yorgunluğu, göz rahatsızlığı yaşadıklarını belirten katılımcıların kronik baş ağrısı şikayetleri de söz konusudur. Bazı katılımcı ifadeleri aşağıdaki gibidir.

\footnotetext{
"Kulağımda biraz sıkıntı var. Sol kulağımda çağrı almamdan kaynaklı duyabilme yeteneğimi kaybediyorum" K6.
}

"Să̆ kulağımda ciddi duyma kaybı oldu” K3. 
"Birgün sesim hiç çıkmadl, meğer ses teli iltihabı olmuşum. 10 gün rapor verdiler" $K 5$.

"Ses tellerimde nodüller oldu, tüm müşsteri temsilcilerinde oluyor zaten" $\mathrm{K} 9$.

"Sürekli başım ağrıyor” K7.

"Migrene yol açıyor" K9.

“Gözlerimin çok yorulduğunu hissediyorum” K10.

Meslek hastalığı kavramı 5510 Sayılı Sosyal Sigortalar ve Genel Sağlık Sigortası Kanunu 14. Md. 1. Fıkrasında "sigortalının çalıştığ1 ve yaptığı işin niteliğinden dolayı tekrarlanan bir sebeple veya işin yürütüm şartları yüzünden uğradığı geçici veya sürekli hastalık, bedensel veya ruhsal engellilik halleri" olarak tanımlanmaktadır. Bu noktadan hareketle katılımcıların bahsettiği sorunlar çağrı merkezlerinde çalışma koşullarının neden olduğu meslek hastalıkları olarak ele alınmalıdır. Ancak çoğunlukla bu hastalıklar meslek hastalığı resmi prosedürü dışında tanı ve tedavi gördüğü için meslek hastalığı olarak raporlanmamaktadır.

Çalışanlar için sağlığı tehdit eden diğer bir faktör de çağrı merkezlerindeki fiziki şartlardır. 8- 10 oda büyüklüğünde ofislerde onlarca kişi gün boyu çağrı almaktadır. Sesin yayılmaması için alınan yerlerin ve masaların halı vb. maddelerle kaplı olması hijyen sorunlarını beraberinde getirmektedir. Ofislerde klimalarla ısınma ve serinletme sağlanması kışın gereğinden sıcak, yazın gereğinden soğuk bir ortam yaratabilmektedir. Yapay 1şıklandırmaların şiddeti her zaman sağlık için uygun koşullarda olmamaktadır (Yücesan- Özdemir, 2019: 49). Fiziki koşullara bağlı sorunların dile getirilme yoğunluğu \% 70 olarak gerçekleşmiştir. Konuyla ilgili bazı ifadeler şu şekildedir;

"Bizim orda ısınma sorunu var, yazın sıcak, kışın soğuk ayarlayamiyorlar" $\mathrm{K} 1$.

“Kimi fazla üşüyor, kimi fazla sıcaklıyor, klimaların yeri yanlış” K7.

"Sicaklık ve aşırı gürültü var” K2.

"Herkesin sesi birbirine karıșıyor” K9. 


\section{Sendikalaşma Temasına İlişkin Sonuçlar}

Çağrı merkezleri genç çalışan profili, yüksek işgücü devri, geçici iş olarak görülmesi, çağrı merkezlerinin işkolu belirlenmesinin geç olması gibi nedenlerle sendikalaşma oranlarının yeterli olmadığı görülmektedir. Yapılan araştırmada hiçbir katılımcının sendika üyesi olmadığı görülmüştür. Diğer yandan katılımcılar sendikaların çalışma yaşamındaki sorunları gidermeye yönelik olumlu hamleler yapacağına dair olumlu bir tutum sergilemelerine rağmen sendika üyeliği hakkında yeterli bilgiye sahip değillerdir. Katılımcıların temaya ilişkin verdikleri yanıtların frekansları Şekil 6'da gösterilmektedir.

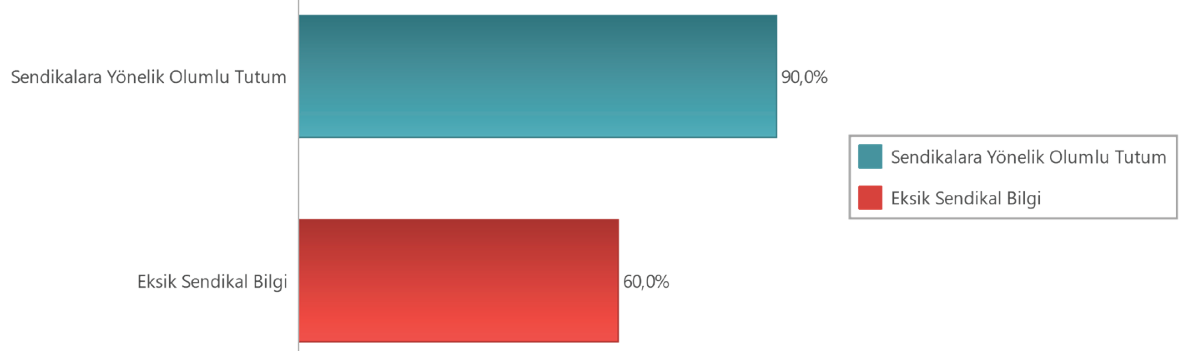

Şekil 6. Sendikalaşma Teması Alt Kodlarına İlişkin Frekanslar

Katılımcıların sendikalara yönelik olumlu tutumlarına (\% 90) rağmen üye olmamalarının önemli bir nedeni sendikal haklara ilişkin eksik bilgilerdir. Katılımcıların bir kısmı sendikalara işyerinin izin vermesi halinde üye olabileceklerini düşünmekte, bir kısmı ise çağrı merkezi çalışanlarının üye olabileceği bir sendika olup olmadığını bilmediklerini ifade etmektedirler. Konuyla ilgili bazı ifadeler aşağıda verilmiştir.

"Dayanamıyor kimse. İşten çıkarıyorlar. O yüzden sendikanın devamlılık sağlayabileceğini sanmiyorum” $K 2$.

"Aslında sendikalı olmak isterdim. Bildiğim kadart ile hakları koruyabilirdi, sorunlara çözüm bulurdu. Şimdi yalnızız, bir dayană̆ımı yok” $K 7$.

"Çağrı merkezi ile ilgili sendika var mı bilmiyorum, olsaydı kesin üye olurdum" $K 4$.

“Özel şirket olduğu için sendika yasak” K8.

"Sendikalı çalışmiyoruz, kadroluyuz biz” K10. 
Günümüzde sendikalaşma oranları giderek düşmektedir. Çalışma koşullarının Fordist- Taylorist fabrikalara benzetilmesi açısından da çağrı merkezleri sendikaların örgütlenmesi gereken önemli boş alanlardır. Sektörde sendikalaşma oranlarının arttırılması öncelikle çalışanların sendikal hakları konusunda bilgilendirilmesi ile başlayacaktır. Sendikal bilincin artması ve sendikaların çalışan sorunlarını çözmeye yönelik yapabileceklerinin çalışanlara anlatılması bu sektördeki sendikalaşma oranlarını arttıracaktır. Sendikal örgütlenme ve baskının sektördeki bazı yıpratıcı çalışma koşullarını yumuşatması kuvvetle muhtemeldir. Yapılan bazı çalışmalarda (Taylor ve Bain, 1999) sendikaların bu sektörde bir takım kazanımlara yol açtığını göstermektedir.

\section{Memnun Olunan Yönler Temasına İlişkin Sonuçlar}

Yaşanan pek çok sıkıntıya rağmen çalışanların neden çağrı merkezinde çalışmayı seçtikleri ve sürdürdüklerini belirleyebilmek için katılımcılara “işinizin memnun edici tarafları nedir?” sorusu yöneltilmiştir. Verilen yanıtlar 5 alt temada yoğunlaşmıştır. Şekil 7’de alt kodlar gösterilmiştir.

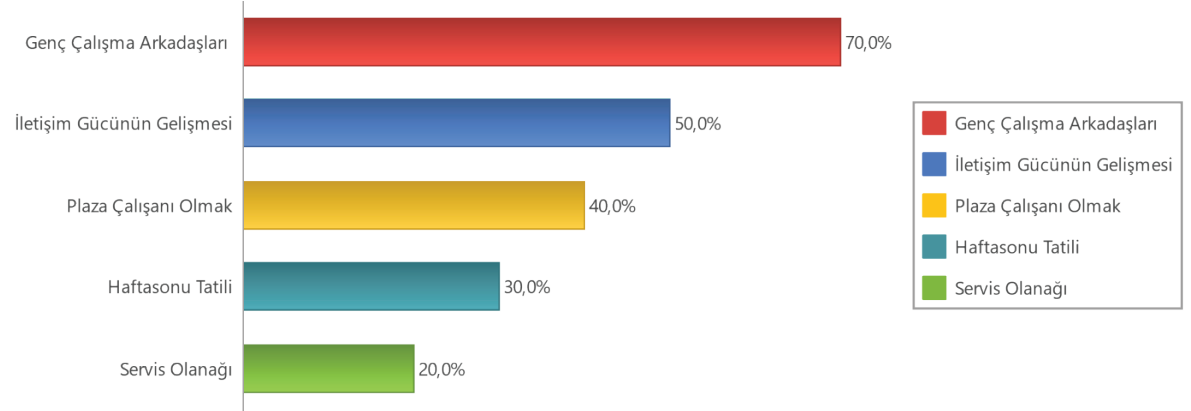

Şekil 7. Memnun Olunan Yönler Teması Alt Kodlarına İlişkin Frekanslar

Katılımcılar yaptıkları işin en memnun edici tarafı olarak genç ve kafa dengi çalışma arkadaşlarını görmektedirler (\% 70). "İşi çekilir kılan tek şey arkadaşlık ortamı” K2 ve “Arkadaş ortamı beni burada tutan yegane șey” K5 gibi ifadeler çalışma ortamındaki genç ve dinamik ortamın bir motivasyon ve işe bağl1lık unsuru olarak görüldüğünü ortaya koymaktadır. Çağrı merkezlerinde çalışanların işlerinden memnuniyet konusunda \% 50 oranında vurguladıkları diğer faktör yapılan işle ilgili verilen eğitimlerin ve çağrılarda karşılaşılan sorunların bireysel iletişim, sorun çözme becerisi ve kriz yönetme gücünü geliştirmesidir. 
Katılımcılar gerek düzenli olarak verilen eğitimlerde gerekse günlük deneyimleri sonucunda kişisel gelişim sağladıklarını, deneyim kazandıkları ifade etmişlerdir. Bazı katılımcı ifadeleri şu şekildedir;

"Sosyal hayatımda karşılaştı̆̆ım sorunları farklı bakış açısından çözebilmemi să̆llyor, aldiğın eğitimler kendini geliştirme firsatı veriyor" $K 9$.

"Yeni bir şeyler kazandırlyor, kendini ifade etme özgürlügüü oluyor" K1.

Çağrı merkezlerinin gençler tarafından tercih edilmesinin diğer bir nedeni de asgari ücret ve sosyal güvence sağlayan masa başı iş ve plaza çalışanı olmaktır. Katılımcılar da \% 40 oranında bu sonucu vurgulamışlardır. Günümüz koşullarında genç ve yükseköğretim mezunu işsizlik oranları çok yüksek olduğu için gençler mezuniyet sonrasında uzun süreli işsiz kalmakta ya da işsiz kalmaktansa bazı işleri tercih etmek durumunda kalmaktadırlar. Katılımcılardan bazıları daha önceki işlerinde bedenen çok yoruldukları ve vardiyalı çalıştıklarını, çağrı merkezinde ise "hiç olmazsa masa başında çalıştıklarını ve mesaiye kalmadıklarını" ifade etmişılerdir.

“Fiziki yapı olarak tam bir plaza merkezi” K5.

"Daha sert işlerde çalıştım, daha böyle gecesi gündüzü olmayan... Kışın sıcak, yazın soğuk, masa başı, rahat olacak şekilde bir iş istiyordum, hayalim buydu. İki sene önce tam hayalimdeki gibi girdim, rahatlı̆̆ından konumundan dolayı. Bir çalışan işin servisi, yemeği var, masa başı işi, bilgisayar başındasın. Başka arkadaşlarımız var, maaşı yatmıyor, SGK sl yatmıyor. Bizim günü gününe yatıyor mesela” K10.

Hafta sonu tatili ve servis olanağ 1 katılımcıların diğer memnuniyet belirttiği alt kodlar olmuştur. Araştırmanın yapıldığ işyerinde "işler yoğun olduğu ve hedefler tutmadığı zaman” hafta sonu çalışması yapılmakta ve fazla çalışma ödemesi yapılmamasına rağmen katılımcılar hafta sonu çalışmamalarını işlerinin avantajı olarak görmektedirler (\% 30). Evlerinden işe servis aracı ile ulaşım da katılımcıların avantaj olarak belirttiği sosyal haklardandır (\% 20). 
Katılımcıların en çok değindikleri temalar ve alt kodlara ilişkin kod matrisi Şekil 8'de gösterilmiştir. Kod matrisinden görüldüğü üzere katılımcıların en yoğun olarak vurguladıkları alt kodlar; meslek hastalığı, yönetici ve müşterilerle yaşanan sorunlar olmuştur. Yoğun olarak değinilen diğer alt kodlar, sendikalara yönelik olumlu tutum, yaptıkları işin geçici bir iş olarak görülmesi, ücret ve primler, mola süreleri ve satış baskısıdır.

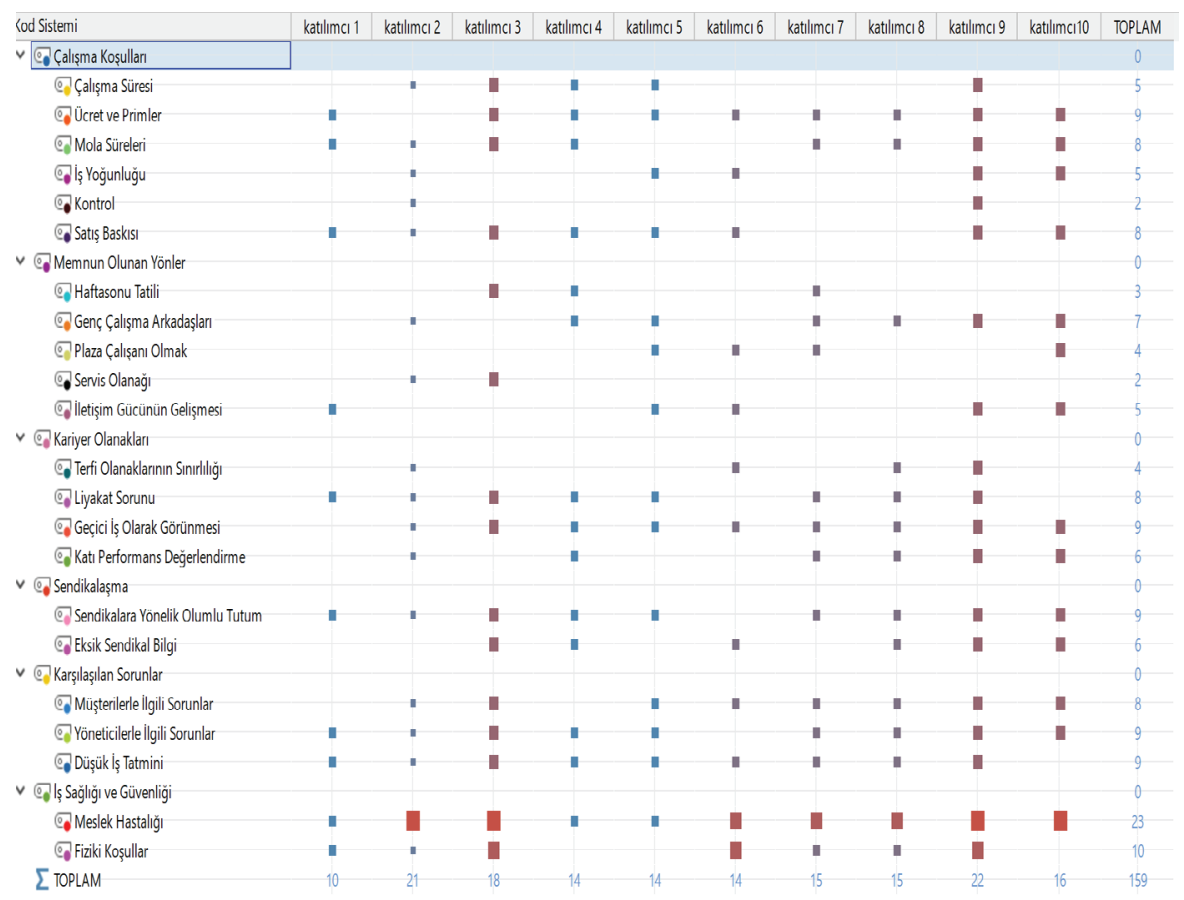

Şekil 8. Tema ve Alt Kodlara İlişkin Kod Matrisi

\section{Sonuç}

Bilgi sektörünün yükselişi ile sanayi toplumundaki üretim sürecinde bazı köklü değişiklikler yaşanmıştır. Bilgi toplumunda ekonomik büyümenin kaynağı bilginin üretilmesi ve işlenmesi haline gelmiştir. Geleneksel sanayi üretimindeki sermayenin yerini “insan ve bilgi” sermayesi almıştır. Üretim sürecinin başlıca aktörleri arasında bilgisayarlar, telekomünikasyon araçları ve yeni teknolojiler sayılmaktadır. Bu dönüşüm bazı meslekleri ortadan kaldırırken iletişim ve teknoloji temelli bazı meslekleri de üretmiştir. Çağnı merkezleri bilgi toplumu sonrası hızla artmaya başlayan yeni bir iş alanı olarak karşımıza çıkmıştır. 
Çağrı merkezi çalışanları, bilgi toplumunun beyaz yakalı çalışanları olmasına rağmen çalışma koşulları bakımından Fordist üretim sistemine benzer ve Taylorist ilkelere maruz bir görünüm sergilemektedirler. Geneli yükseköğrenim mezunu, iyi giyimli ve güzel Türkçe konuşan, genç, plaza çalışanı görünümündeki bu gençler aslında tam zamanlı ve sigortalı bir iş bulmaları karşılığında sanayi devrimi işçilerinin güncel bir şekline bürünmüşlerdir. Çağrı merkezleri rutin ve standart işlerin yapıldığı, iş yoğunluğunun, kontrol ve denetimin, işgücü devrinin çok yüksek olduğu olumsuz çalışma koşullarına sahip çalışma alanları olarak karşımıza çıkmaktadır. Bilgi çağının yarattığı işgücü tipi esnek çalışan, bireysel pazarlık gücü ve vasıfları yüksek bir görünümdedir. Oysaki çağrı merkezleri nitelikli, eğitimli, bilgi işçisi vasıflarındaki işgücünden FordistTaylorist beklentilerini sürdürmektedir. Bilgi işçisinin yaşadığı avantajlar çağrı merkezi çalışanları için söz konusu olmadığı gibi bu çalışanların sanayi devrimi dönemine benzer kötü koşullara maruz kalmaktan kurtulamamaktadır. Bu özellikleri itibari ile bazı yazarlarca (Taylor ve Bain, 1999; Başbuğ vd. 2010: 260; Özkan, 2013: 65; Doğanay, 2016: 53; Bulut ve Ataay, 2017: 4-5; YücesanÖzdemir, 2019: 199) çağrı merkezleri "zihinlere üretim bandı kuran" modern dünyanın fabrikaları olarak tasvir edilmektedir.

$\mathrm{Bu}$ araştırmada çağrı merkezlerinde çalışan müşteri temsilcilerinin çalışma yaşamındaki sorunları belirlenmeye çalışılmıştır. Literatürde gelen arama alan müşteri temsilcilerinin sorunlarına yönelik araştırmalar mevcuttur. Giden arama yapan müşteri temsilcilerini ayrıca ele alan bir araştırma bulunmamaktadır. Giden arama yapan müşteri temsilcileri müşterilerin müsait olup olmadığını bilmeksizin arama yaptıkları için ve "satış yapma" baskısı altında olmaları nedeni ile ekstra baskı hissedebilmektedirler. Bu nedenle bir bankanın giden arama yapan müşteri temsilcileri çalışma grubu olarak seçilmiştir.

Araştırmada cevabı aranan ilk soru müşteri temsilcilerinin karşılaştıkları sorunlar olmuştur. Müşteri temsilcilerinin karşılaştıkları sorunlar literatürdeki sonuçlara uygun 5 tema ile gruplanmıştır. Araştırma sonucunda katılımcıların tamamının çağrı merkezinde çalışmaya başladıktan sonra duyma kaybı, kronik faranjit ve ses teli iltihabı, baş ağrısı gibi şikayetler yaşamaya başladıkları tespit edilmiştir. Çalışma saatleri haftada 45 saat olmakla birlikte "gerekli görüldüğü taktirde" çalışanlar hafta sonu da çalıştırılmakta ve bu çalışma fazla çalışma olarak sayılmamaktadır. Çalışanlar asgari ücret artı prim usulü ile çalışmakta ancak prim alma koşulları yüksek hedefleri tutturma, çağrıları çok kısa sürede 
tamamlama ve hiç hata yapmama koşullarına bağlı olarak zorlu koşullara bağlanmıştır. Katılımcılar yaptıkları işin karşılığında ücret ve primin çok yetersiz olduğunu ifade etmektedirler.

Çalışma koşullarını zorlu hale getiren diğer önemli bir nokta günlük alınan çağrı süreleri ve karşılığında kullanılan mola süreleridir. Çağrıların otomatik bilgisayar dağıtıcısı tarafından yönlendirilmesi sonucu telefonu kapanan müşteri temsilcisine neredeyse 10 saniye aralıklarla yeni çağrı bağlanmaktadır. Bu durum katılımcıların mola süreleri dışındaki zamanlarının önemli bir kısmını çağrıda geçirdiklerini göstermektedir. Elli dakikalık çağrı süresi sonunda 10'ar dakikalık molalar çalışanların dinlenmesi, nefes alması, temel ihtiyaçlarını karşılaması için yetersiz kalmaktadır. Katılımcıların tamamı çağrı sürelerinin bu kadar aralıksız olmasının işi "sürekli yapılabilir, emekli olunabilir" bir iş olmaktan çıkardığını belirtmektedirler.

Diğer yandan yapılan çağrılar kayıt altına alınarak çalışanların çok sıkı ve sürekli bir denetim altına alınması sağlanmaktadır. Takım liderleri de sürekli çalışanlar arasında dolaşıp gözetim yapmaktadır. Birkaç dakika çağrı almayan müşteri temsilcileri kontrol edilerek hemen yeni çağrı bağlanmasını sağlanmaktadır. Verilen yüksek hedefler de çalışanlar üzerinde zorlayıcı bir baskı oluşturmaktadır. Satış baskısı oluşturmak için yüksek hedefler konulmakta, üstün performans göstererek bu hedeflere ulaşanlara aynı gün daha yüksek hedefler verilmektedir.

Çağrı merkezlerini çalışabilir mekanlar olmaktan uzaklaştıran diğer bir faktör de kariyer olanaklarının sınırlılığı ve yükselme önündeki engellerdir. Çağrı merkezleri içinde terfiler takım lideri ve şeflikle sınırlı bulunmaktadır. Katılımcılar terfilerde liyakat sorunundan bahsetmekte ve yükselmelerin sıklıkla kurum dışından sağlandığını ifade etmektedirler. İş yoğunluğu, işin yüksek nitelik gerektirmemesi, monotonlaşması yanında bir de yükselme olanaklarının sınırlılığı çalışanların çağrı merkezlerini "geçici bir iş" olarak görmelerine neden olmaktadır. Emekliliğe kadar giden bir kariyer yolu olarak görülmediği gibi işsiz kalmanın bir alternatifi olarak değerlendirilmektedir.

İkinci araştırma sorusu giden arama yapan müşteri temsilcilerinin yaşadıkları sorunların farklılaşıp farklılaşmadığıdır. Gelen arama yapan müşteri temsilcilerinin görev tanımı arayan müşterilerin sorunlarına çözüm bulmak iken giden arama yapan müşteri temsilcileri bir "pazarlama" görevi 
üstlenmektedir. Bu anlamda temel sorunlar benzer olmakla birlikte giden arama ekibi kendilerine satış hedefi konulduğu ve hedefe ulaşılmadığında ayrıca performans ve baskı sorunları yaşadıklarından bahsetmişlerdir. Satış hedefini tutturamayan müşteri temsilcileri hafta sonu fazla çalışma yapmakta ve bunun için ayrıca ücret almamaktadırlar.

Diğer araştırmalardan farklı olarak çalışanların zorlu koşullara rağmen neden çağrı merkezinde çalışmak istedikleri sorgulanmıştır. Bu çerçevede katılımcıların çağrı merkezlerinde çalışmanın avantajı olarak gördükleri noktalar sorgulamıştır. Katılımcılar genç çalışma arkadaşları ile birlikte olmayı, işsizlik ortamında masa başı ve plaza çalışanı olmayı, hafta sonu tatili ve vardiyasız çalışmayı avantaj olarak görmektedirler. Ancak araştırmanın yapıldığı giden arama ekibi dışındaki çağrı merkezlerinde vardiyalı çalışma ve hafta sonu çalışması olduğu bilinmektedir. Dolayısıyla bu avantaj her çağrı merkezi çalışanını kapsamamaktadır. Katılımcılar "bu işi başkasına önerir misiniz" sorusuna "işsizlerse evet, yoksa etmem" yanıtını vererek avantaj olarak sayılan hallere rağmen tercih edilebilir meslek olmadığını belirtmişlerdir. Elde edilen bu bulgu gençlerin masa başı olması ve sigortalarının zamanında yatması koşuluyla memnun olmadıkları bir işte çalışmaya mecbur kaldıklarını gösterir niteliktedir. İşsizlik oranlarının tüm dünyada arttığ günümüzde bu sektörün genç iş arayanları sömürdüğü düşünülebilir.

Sektörde yaşanan sorunlar 2013 yılında ÇSGB tarafından hazırlanan bir raporla ortaya konmuş olmasına rağmen, 2020 yılında gerçekleştirilen bu araştırmada pekçok sorunun düzeltilemediği görülmektedir. Sendikacılık oranları çağrı merkezi çalışanları arasında çok düşüktür. Sendikalar işgücü devrinin yüksek olmasının da etkisiyle çağrı merkezlerinde örgütlenmekte güçlük yaşamaktadır. Diğer yandan çalışanların bireysel ve kollektif sendikal özgürlükler ve haklar konusunda yeterli bilgiye sahip olmadıkları görülmektedir. Çağrı merkezlerinde yaşanan sorunların çözümünde sendikalar ve toplu iş sözleşmelerinin önemli rol oynayacağı düşünülmektedir. Sendikalar bu çalışanların bilinçlenmesi ve sendikalaşması için özel bir çaba sarf etmelidir. $\mathrm{Bu}$ araştırmada katılımcıların sendikal haklarına ilişkin bilgilerinin eksik olmasına karşı1ık sendikalara yönelik olumlu tutumları olduğu belirlenmiştir. Sendikal bilginin arttırılması ile olumlu tutuma sahip çalışanların sendika üyesi olması sağlanabilecektir. Bundan sonraki çalışmalarda çağrı merkezi çalışanlarının sendikalaşması önündeki engeller incelenebilir. 
Hakem Değerlendirmesi: Dış bağımsız.

Çıkar Çatışması: Yazar çıkar çatışması bildirmemiştir.

Finansal Destek: Yazar bu çalışma için finansal destek almadığını beyan etmiştir.

Peer-review: Externally peer-reviewed.

Conflict of Interest: The author has no conflict of interest to declare.

Grant Support: The author declared that this study has received no financial support.

\section{Kaynakça/References}

Akal, D. (2016). Çağrı Merkezi Çalışma Ortamının Elektromanyetik Alan Ölçümü ile İş Sağlığl ve Güvenliği Yönünden Değerlendirilmesi, Gazi Üniversitesi, Fen Bilimleri Enstitüsü, Kazaların Çevresel ve Teknik Araştırması Anabilim Dalı, Yayımlanmamış Yüksek Lisans Tezi: Ankara.

Aktan, C. C. ve Tunç, M. (1998). Bilgi Toplumu ve Türkiye, Yeni Türkiye, Ocak- Şubat, ss. 118- 134.

Baltacı, A. (2018). Nitel Araştırmalarda Örnekleme Yöntemleri ve Örnek Hacmi Sorunsalı Üzerine Kavramsal Bir İnceleme, Bitlis Eren Üniversitesi, Sosyal Bilimler Enstitüsü Dergisi, Cilt: 7, Say1: 1, Haziran, ss. 231- 274.

Başbuğ, G.; Ballı, E. ve Oktuğ, Z. (2010). Duygusal Emeğin İş Memnuniyetine Etkisi: Çağrı Merkezi Çalı̧̧anlarına Yönelik Bir Çalışma, Sosyal Siyaset Konferansları Dergisi, Cilt: 58, Say1: 1, ss: 253- 274.

Bulut, U. Ve Ataay, A. (2017). Çağrı Merkezlerinde Çalışan Performansını Etkileyen Faktörler: Bir İnceleme, İ̧sletme Araştırmaları Dergisi, Cilt: 9, Sayı: 4, ss. 1- 16.

Çağrı Merkezleri Derneği (2019). Türkiye Çağrı Merkezi Pazarı, 2019 Verileri, www. cagrimerkezleridernegi.org/Public/Upload/Catalog/5OV8UZISEIAEOGG.pdf (Erişim Tarihi: 04.04.2020)

Çalışma ve Sosyal Güvenlik Bakanlığı (2013). Çağrı Merkezlerinde Çalışma Koşullarının İyileştirilmesine ve Sosyal Tarafların Bilinçlendirilmesine Yönelik Teftiş Programı Sonuç Raporu, İş ve Teftiş Kurulu Başkanlığı, Yayın No: 58, Ankara.

Çelik, N. (2016). Türkiye'de Çağrı Merkezi Sektörü Sorunlarının Çözümüne Yönelik Bir Kara Destek Sistemi Geliştirme, Uluslararası Sosyal Araştırmalar Dergisi, Cilt: 9, Say1: 42, Şubat, ss. 1445- 1453.

Çil, Ş. (2007). 4857 Sayılı İş Kanununa Göre Fazla Çalışma ve Fazla Sürelerle Çalışma, Çallşma ve Toplum, Sayı: 3, ss.57-79.

Doğanay, S. (2016). İş Örgütlerinde Kontrol ve Rıza Mekanizmalarının İşleyişi, Yönetim ve Organizasyon Araştırmaları Dergisi, Cilt: 1, Sayı: 2, Ekim, ss. 31- 58.

Erdem, Z. (2005). Sanayi İşçisi”nden “Bilgi İşçisi”ne: Yeni Ekonomi’nin Değişen İşçi Tipi, Sosyal Siyaset Konferansları Dergisi, Say1: 49, ss. 541- 566. 
Erinç, Ç. D. (2007). Çă̆rı Merkezlerinde Çalışma Yaşamı, Sakarya Üniversitesi, Sosyal Bilimler Enstitüsü, İnsan Kaynakları Anabilim Dalı, Yayımlanmamış Yüksek Lisans Tezi, Sakarya.

Grebner, S.; Semmer, N.; Faso, L. L.; Gut, S.; Kalin, W. ve Elfering, A. (2003). Working Conditions, Well-Being, and Job Related Attitudes Among Call Centre Agents, European Journal of Work and Organizational Psychology, Cilt: 12, Say1: 4, ss. 341365.

Gümüş, M. (2002). Günümüzün Gelişen Sektörü Çağrı Merkezleri, Sakarya Üniversitesi Fen Bilimleri Enstitüsü Dergisi, Cilt: 6, sayı: 2, Temmuz, ss. 134- 141.

Karademir, Ö.; Karakulle, İ. (2013). Bilgi Toplumunda Sekreterlik Mesleğine Genel Bakış, Süleyman Demirel Üniversitesi Sosyal Bilimler Enstitüsü Dergisi, 2013/ 1, ss. 207- 221.

Karademir, E.; Sarıkahya, E.; Altunsoy, K. (2017). Fen Bilimleri Öğretmenlerinin Beceri Kavramına Yönelik Algıları: bir Olgubilim Çalışması, Eskişehir Osmangazi Üniversitesi, Sosyal Bilimler Dergisi, Cilt: 18, Say1: 1, Haziran, ss. 53- 71.

Keser, A. (2006). Çağrı Merkezi Çalışanlarında İş Yükü ile iş Doyumu İlişkisinin Araştırılması, Kocaeli Üniversitesi Sosyal Bilimler Enstitüsü Dergisi, Cilt: 11, Sayı: 1, ss. 100- 119 .

Kurt Uğur, P. (2010). Çalışma Hayatının Kalitesi ve Çağrı Merkezi Uygulamaları, Marmara Üniversitesi, Sosyal Bilimler Enstitüsü, İşletme Ana Bilim Dalı, Yayınlanmamış Yüksek Lisans Tezi.

Lewig, K A; Dollard, M. F. (2003). Emotional Dissonance, Emotional Exhaustion and Job Satisfaction in Call Centre Workers, European Journal of Work and Organizational Psychology, Cilt: 12, Say1: 4, ss. 366- 392.

Man, F. ve Selek Öz, C. (2009). Göründüğü Gibi Olmamak Ya Da Olduğu gibi Görünememek: Çağrı Merkezlerinde Duygusal Emek, Çalışma ve Toplum, Cilt: 20, Say1: 1, ss. 75- 94.

Menteşe, B. ve Es, M. (2017). Türkiye'de Çağrı Merkezlerinde Çalışma İlişkileri: Yalova, Elazı̆̆ ve Şanlıurfa Örneği, Yalova Sosyal Bilimler Dergisi, Yıl: 8, Sayı: 14, Ekim, ss. 23- 50 .

Okur, A. (2018). Çăgrı Merkezi Operatörlerinin Çalışma Şartlarının İş Sağlı̆̆ı ve Güvenliği Açısından Değerlendirilmesi, Üsküdar Üniversitesi, Sağlık Bilimleri Enstitüsü, İş Sağlığı ve Güvenliği Anabilim Dalı, Yayımlanmamış Yüksek Lisans Tezi, İstanbul.

Özkan, G. (2013). Çağrı Merkezlerinde Duygusal Emek ve Örgütsel İletişim, Selçuk Iletişim Dergisi, Cilt: 7, Sayı: 4, ss. 64- 80.

Parlak, Z. ve Çetin, B. I. (2007). Bilgi Toplumu ve Bilgi İşçisi Bağlamında Çağrı Merkezleri: Emek Süreci, İş ve İstihdam, Sosyal Siyaset Konferansları Dergisi, ss. 107- 134 . 
Seçkin, E. ve Ökten, A. N. (2009). Az Gelişmiş Bölgelerin Gelişmesinde Bir Fırsat Olarak Çağrı Merkezleri, Megaron Dergisi, Cilt: 4, Say1: 3, ss. 191- 202.

Seçkin, E. ve Ökten, A. N. (2016). Emek Piyasasındaki Bölünme: Türkiye’de Çağrı Merkezi Sektörü, Toplum ve Bilim Dergisi, Say1: 135, ss. 74- 91.

Selvi, Ö. (2012). Bilgi Toplumu, Bilgi Yönetimi ve Halka İlişkiler, Gümüşhane Üniversitesi, Iletişim Fakültesi Dergisi, Cilt: 1, Sayı: 3, Mart, ss. 191- 214.

Tartanoğlu, Ş. (2014). Çă̆rı Merkezlerinde Denetim-Direniş İlişkileri Bağlamında Enformel Örgütlenmenin Koşulları ve Sonuçları: Çağrı Merkezi Çalışanları Derneği Örneği, Uludağ Üniversitesi, Sosyal Bilimler Enstitüsü, Çalışma Ekonomisi ve Endüstri İlişkileri Anabilim Dalı, Yayımlanmamış Doktora Tezi, Bursa.

Taylor, P. ve Bain, P. (1999). An Assembly Line in the Head: Work and Employee Relations in the Call Centre, Industrial Relations Journal, Cilt: 30, Say1: 2, ss. 101- 117.

Taylor, P. ve Bain, P. (2001). Trade Unions, Workers' Risghts and the Fronties of Control in UK Call Centres, Economic and Industrial Democracy, Cilt: 22, Say1: 1, ss. 39- 66.

Turgut, F. (2014). Tükenmişlik Sendromuna Etki Eden Faktörler (Antalya 112 Acil Çağrı Merkezi Çalışanları Örneği), Beykent Üniversitesi, Sosyal Bilimler Enstitüsü, İşletme Yönetimi Anabilim Dalı, Yayınlanmamış Yüksek Lisans Tezi, İstanbul.

Türkiye Bankalar Birliği (2019). Çağrı Merkezi İstatistikleri, İstatistiki Raporlar, Rapor kodu: DT23, Temmuz.

Törün, A. (2006). Müşteri İlişkileri Yönetiminin Araçlarından Biri Olarak Çăgrı Merkezleri, Çağrı Merkezi Bölümü Çalışanları ve Memnuniyet: Bir Araştırma, İstanbul Üniversitesi, Sosyal Bilimler Enstitüsü, İşletme Anabilim Dalı, Yayınlanmamış Yüksek Lisans Tezi.

Yaşar, A.; Alpsoy, F.; Taçgın, E. (2016). Çağrı Merkezlerinin İş Sağlığı ve Güvenliği Açısından Değerlendirilmesi, Ankara Üniversitesi Sosyal Bilimler Dergisi, Cilt: 7, Say1: 1, ss. 1- 29.

Yıldırım, A. ve Şimşek, H. (2016). Sosyal Bilimlerde Nitel Araştırma Yöntemleri, Seçkin Yayınevi, Ankara.

Yorgun, S. (2005). Türk Sendikacılığında Yeni Yönelişler ve Alternatif Öneriler, Çalışma ve Toplum Dergisi, 2005/ 3, ss. 137- 162.

Yücel Tüfekçioğlu, E. (2015). 3 farklı Bölgedeki Çağrı Merkezi Çalışanlarında Genel Să̆lık Durumu ve Tükenmişlik Düzeyi, İstanbul Üniversitesi, Cerrahpaşa Tıp Fakültesi, Halk Sağlığı Anabilim Dalı, Yayımlanmamış Uzmanlık Tezi, İstanbul.

Yücesan-Özdemir, G. (2019). Anlatılan Senin Hikayendir, Çağrı Merkezinde Çalışmak, Notabene Yayınevi, İstanbul.

Zaim, H. (2005). Yeni Gelişmeler Işı̆̆ında Bilgi İşi ve Bilgi İşçisi, Sosyal Siyaset Konferanslarl Dergisi, Sayı 49, ss. 589- 610. 
